\title{
Groundwater Monitoring Plan for the Nonradioactive Dangerous Waste Landfill
}

\author{
J. W. Lindberg
}

M. J. Hartman

August 1999

Prepared for

the U.S. Department of Energy

under Contract DE-AC06-76RLO 1830

Pacific Northwest National Laboratory

Richland, Washington 99352 



\section{DISCLAIMER}

This report was prepared as an account of work sponsored by an agency of the United States Government. Neither the United States Government nor any agency thereof, nor any of their employees, make any warranty, express or implied, or assumes any legal liability or responsibility for the accuracy, completeness, or usefulness of any information, apparatus, product, or process disclosed, or represents that its use would not infringe privately owned rights. Reference herein to any specific commercial product, process, or service by trade name, trademark, manufacturer, or otherwise does not necessarily constitute or imply its endorsement, recommendation, or favoring by the United States Government or any agency thereof. The views and opinions of authors expressed herein do not necessarily state or reflect those of the United States Government or any agency thereof. 


\section{DISCLAIMER}

Portions of this document may be illegible in electronic image products. Images are produced from the best available original document. 


\section{Summary}

The Nonradioactive Dangerous Waste Landfill (NRDWL), which received nonradioactive hazardous waste between 1975 and 1985 is regulated under the Resource Conservation and Recovery Act of 1976 (RCRA) and monitored by Pacific Northwest National Laboratory. Monitoring is done under interimstatus, indicator-evaluation requirements (WAC 173-303 and by reference, 40 CFR 265.92). The well network includes three upgradient and 6 downgradient wells. The wells are sampled semiannually for contaminant indicator parameters and site-specific parameters and annually for groundwater quality parameters.

Upgradient Wells

Downgradient Wells

Groundwater Quality Parameters

Contaminant Indicator Parameters

Site-Specific Parameters
699-26-34A

699-26-35A (shared with Solid Waste Landfill)

699-26-35C

699-25-33A

699-25-34A

699-25-34B

699-25-34D

699-26-33

699-26-34B

Chloride

Iron

Manganese

Phenols

Sodium

Sulfate

$\mathrm{pH}$

Specific Conductance

Total Organic Carbon

Total Organ Halogens

Nitrate

Volatile Chlorinated Hydrocarbons

The purpose of this plan is to describe an efficient groundwater monitoring program that is capable of determining whether waste disposal at NRDWL has impacted groundwater quality in the uppermost aquifer. 



\section{Contents}

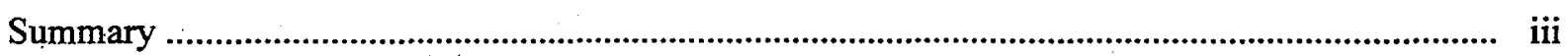

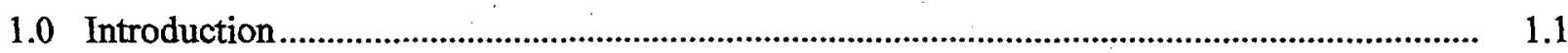

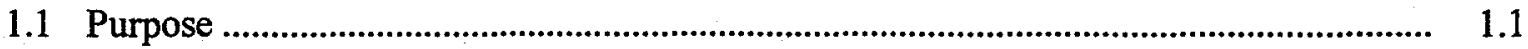

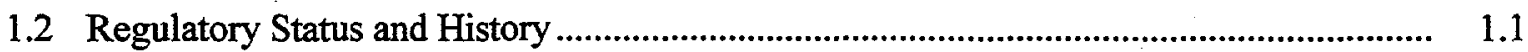

2.0 Description of the Nonradioactive Dangerous Waste Landfill .......................................... 2.1

2.1 Physical Structure and Operational History .............................................................. 2.1

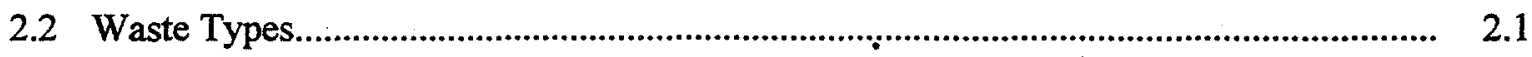

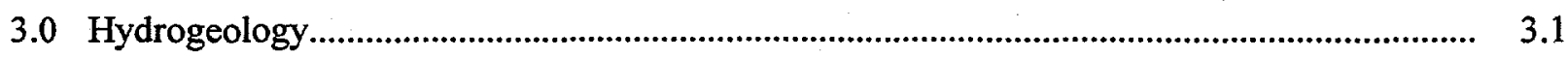

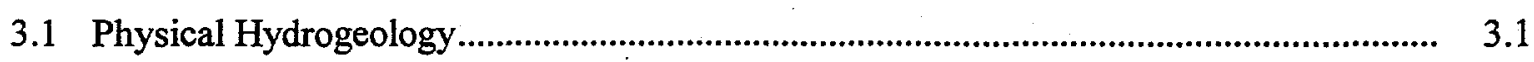

3.2 Summary of Groundwater Monitoring Results ...........................................................

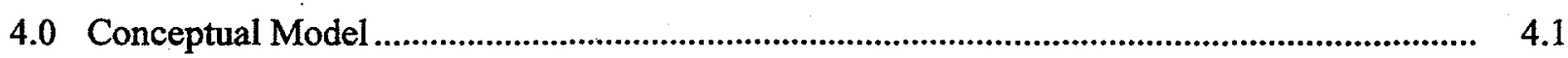

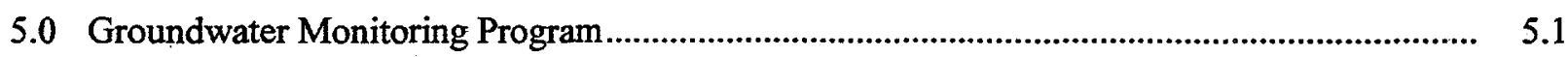

5.1 Objectives of RCRA Monitoring .......................................................................... 5.1

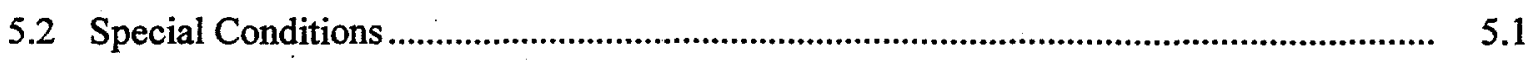

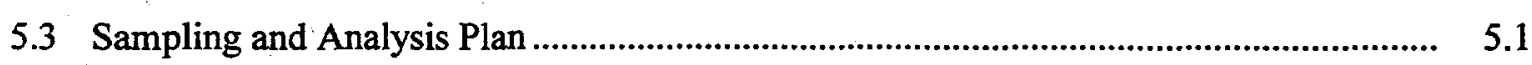

5.3.1 Monitoring Well Network ................................................................................ 5.1

5.3.2 Constituent List and Sampling Frequency ................................................... 5.4

5.3.3 Determination of Groundwater Flow........................................................... 5.4

5.3.4 Sampling and Analysis Protocol ....................................................................... 5.5

5.3.5 Quality Assurance and Quality Control ........................................................ 5.5

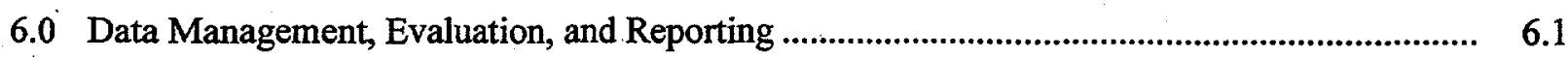

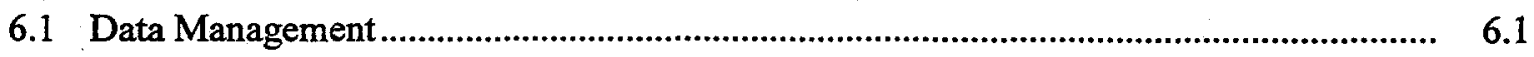

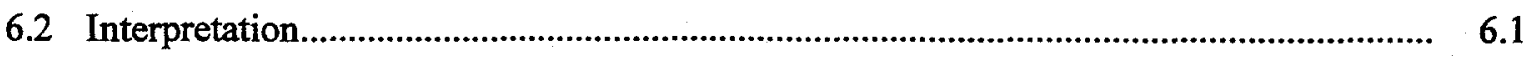

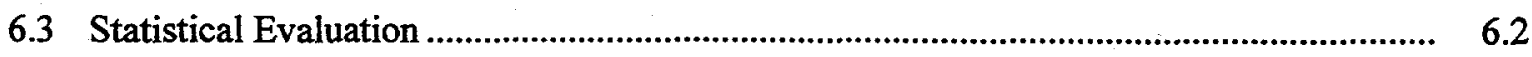

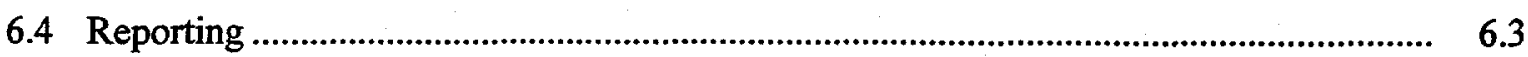


7.0 Assessment Monitoring

8.0 References.

Appendix A - Construction Details of Wells in the Monitoring Network

\section{Figures}

1.1 Location of the Nonradioactive Dangerous Waste Landfill............................................... 1.2

3.1 Stratigraphic Column at the NRDWL and Associated Hydrogeology ................................... 3.2

3.2 Water Table Map for Nonradioactive Dangerous Waste Landfill and Solid Waste Landfill, June 1998

3.3 Water-Table Elevations in Wells Monitoring Nonradioactive Dangerous Waste Landfill ....... 3.5

3.4 Tetrachloroethene Concentrations in NRDWL Wells .......................................................

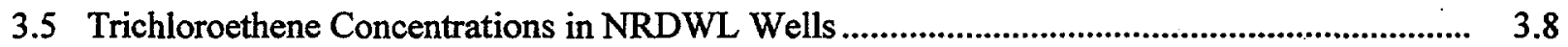

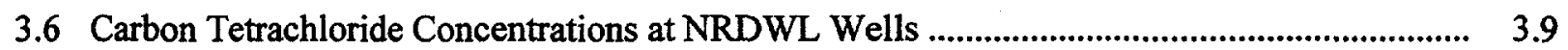

3.7 1,1,1-Trichloroethane Concentrations at NRDWL Wells .................................................. 3.9

3.8 Chloroform Concentrations in NRDWL Wells.................................................................. 3.10

5.1 Monitoring Well Locations for Solid Waste Landfill and Nonradioactive Dangerous Waste Landfill........................................................................................................................ 5.3

\section{Tables}

3.1 Range and Average Concentration of Detected Chlorinated Hydrocarbons in NRDWL Wells, 1987-1998

5.1 Monitoring Well Network.

5.2 Constituent List and Sampling Frequency.

6.1 Critical Means for 28 Comparisons-Background Contamination Indicator Parameter Data for Nonradioactive Dangerous Waste Landfill. 
6.2 Reports Required for Compliance with 40 CFR 265, Subpart F, for Groundwater Monitoring .

7.1 Outline for Groundwater Quality Assessment Monitoring Plan .............................................. 


\subsection{Introduction}

The Nonradioactive Dangerous Waste Landfill (NRDWL), which received nonradioactive hazardous waste between 1975 and 1985, is located in the central Hanford Site (Figure 1.1) in southeastern Washington State. The Solid Waste Landfill, which is regulated and monitored separately, is adjacent to the NRDWL. The NRDWL is regulated under the Resource Conservation and Recovery Act of 1976 (RCRA) and monitored by Pacific Northwest National Laboratory. ${ }^{(a)}$ Monitoring is done under interimstatus, indicator-evaluation requirements (WAC 173-303 and by reference, 40 CFR 265.92). The well network includes three upgradient wells (one shared with the Solid Waste Landfill) and six downgradient wells. The wells are sampled semiannually for contaminant indicator parameters and site-specific parameters and annually for groundwater quality parameters.

\subsection{Purpose}

The purpose of this plan is to describe a streamlined groundwater monitoring program that is capable of determining whether waste disposal at NRDWL has impacted groundwater quality in the uppermost aquifer. This document supersedes all previous monitoring plans (Weekes et al. 1987; Hodges 1993a; Hodges 1995). A revision to Hodges 1993a (Hodges 1995) incorporated the new wells suggested in Hodges monitoring program into the monitoring network and proposed an additional, deep well. Subsequent evaluation indicates that an additional deep well is not needed. The monitoring program proposed in this document is based on current conceptualization of the site and is consistent with data * collected during 12 years of monitoring the site.

\subsection{Regulatory Status and History}

In November 1980, an initial RCRA part A permit application for NRDWL was submitted to the U.S. Environmental Protection Agency. The application was most recently revised in 1990, when a closure/postclosure plan also was submitted (DOE 1990). However, that plan was never approved or implemented.

In 1986, a groundwater monitoring program compliant with WAC 173-303-400(3) and 40 CFR 265, Subpart $F$ (interim status) was required by a consent agreement and compliance order from the Washington State Department of Ecology. These requirements did not change under the Hanford Federal Facility Agreement and Consent Order (Tri-Party Agreement; Ecology et al. 1989). Nine wells were installed, seven of which comprised the initial monitoring network (Weekes et al. 1987). In 1987, quarterly sampling to establish background levels began. Sampling was reduced to a semiannual schedule in 1989 following four quarters of background data collection. Two new wells were installed in 1992. Interim-status indicator evaluation has provided no indication of significant groundwater contamination from NRDWL.

(a) Pacific Northwest National Laboratory is operated by Battelle for the U.S. Department of Energy. 


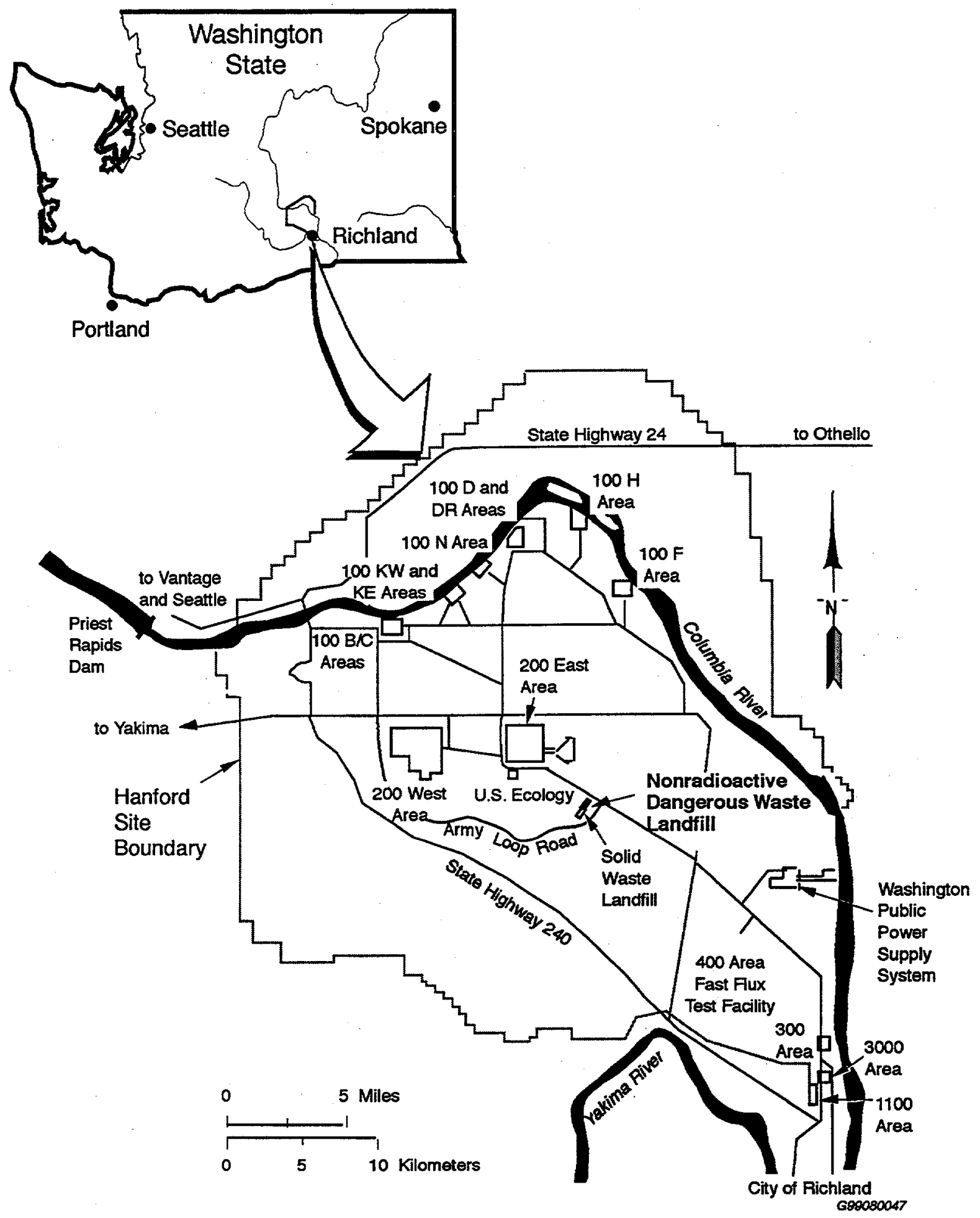

Figure 1.1. Location of the Nonradioactive Dangerous Waste Landfill 


\subsection{Description of the Nonradioactive Dangerous Waste Landfill}

\subsection{Physical Structure and Operational History}

The NRDWL is located $\sim 5.6-\mathrm{km}$ southeast of the 200 East Area on the Hanford Site. The landfill has an area of 4.5 hectares and began operation in 1975. It consists of 19 parallel trenches, each $\sim 122-\mathrm{m}$ long, 4.9-m wide at the base, and 4.6-m deep. Beginning in 1975, chemical waste was disposed of in six trenches, asbestos in nine trenches, nonhazardous solid waste in one trench, and three were unused. The last receipt of dangerous waste was in May 1985, and the last receipt of asbestos occurred in May 1988. At the end of each operating day, the waste containers were covered with soil. This daily burial practice provided a temporary cover for the waste, but a permanent cover is planned for site closure.

The Solid Waste Landfill is adjacent to NRDWL on the south side. It is a larger facility (27 hectare) that received principally solid waste, including paper, construction debris, asbestos, and lunchroom waste. It also received sewage and bus garage wash water. Formerly both landfills were operated as a single landfill (Central Landfill).

\subsection{Waste Types}

The waste disposed of in NRDWL falls into the following categories (Hodges 1993b):

- Bulk organic waste: solvent waste, paints, paint thinners, and waste oils.

- Metal cleaner waste: primarily a mixture of sulfamic acid and sodium bisulfate.

- Small-quantity laboratory chemicals: used and unused reagents and various laboratory formulations, primarily metallic salts, acids, bases, oxidizers, and organic chemicals.

- Asbestos: primarily building demolition material, which accounts for more than $50 \%$ by volume of all waste disposed in the landfill.

- Nonhazardous solid waste: office and lunchroom waste, construction and demolition debris, and septic tank sludge.

Most of the chemical waste was placed in metal drums before disposal. Containers of small-quantity laboratory chemicals were placed in lab-packs and surrounded with sorbing material. Nonhazardous waste and asbestos were generally not placed in containers. In addition, some of the bulk organic wastes that were sorbed onto soil and other sorbents may not have been placed in containers. 


\subsection{Hydrogeology}

The geology and hydrology of the NRDWL site are described in detail by Weekes et al. (1987) and Hodges (1993a). The following summary is taken largely from those documents unless indicated otherwise.

\subsection{Physical Hydrogeology}

The NRDWL is underlain by sands and gravels of the Hanford and Ringold formations (Figure 3.1). The vadose zone is $\sim 40-\mathrm{m}$ thick and consists of sand, silty sandy gravel, and gravel. The water table is near the top of a silty sand unit of the Hanford formation. Saturated sediments are composed of the following units:

- Saturated Hanford sediments: gravelly sand to sandy gravel, 18-m thick; estimated horizontal hydraulic conductivity from field aquifer tests is approximately $1,000 \mathrm{~m} / \mathrm{d}$.

- Upper Ringold and Ringold Formation unit E, divided into three units based on lithology and hydraulic conductivity ( 40 to $45-\mathrm{m}$ thick):

- Slightly silty gravelly sand to sand, $\sim 4-\mathrm{m}$ thick; estimated horizontal hydraulic conductivity from field aquifer tests is $60 \mathrm{~m} / \mathrm{d}$.

- Hard, clayey silt (low permeability) 1 to 4-m thick; estimated vertical hydraulic conductivity from field aquifer tests ranges from 0.006 to $3 \mathrm{~m} / \mathrm{d}$.

- Silty sand to sandy gravel, unknown thickness; estimated horizontal hydraulic conductivity from field aquifer tests ranges from 0.3 to $15 \mathrm{~m} / \mathrm{d}$. This unit is probably unit $\mathrm{E}$, but there are no wells in the vicinity that fully penetrate this unit. Approximately 2-km east at well 699-25-26, the Ringold Formation unit $\mathrm{E}$ is $40 \mathrm{~m}$ thick (Lindsey 1991).

- Ringold Formation unit $\mathrm{C}$, unit $\mathrm{B}$, the lower mud unit, and unit $\mathrm{A}$ are described as follows:

- Unit C, $10 \mathrm{~m}$, gravel and sandy gravel

- Overbank deposit, $20 \mathrm{~m}$, sandy silt and silty sand

- Unit B, $10 \mathrm{~m}$, gravel and sandy gravel

- Lower mud unit, $17 \mathrm{~m}$, silt and sandy silt

- Unit A, $28 \mathrm{~m}$, gravel and sandy gravel

- Top of basalt at $185-\mathrm{m}$ depth

The uppermost aquifer is unconfined and is part of the saturated Hanford sediments and probably the upper portion of the Upper Ringold unit. A low-permeability unit perhaps in the lower portion of the Upper Ringold unit or in unit $\mathrm{E}$ is believed to form the base of the uppermost aquifer because the hydraulic conductivity of the aquifer base is orders of magnitude lower than the overlying sediments. 


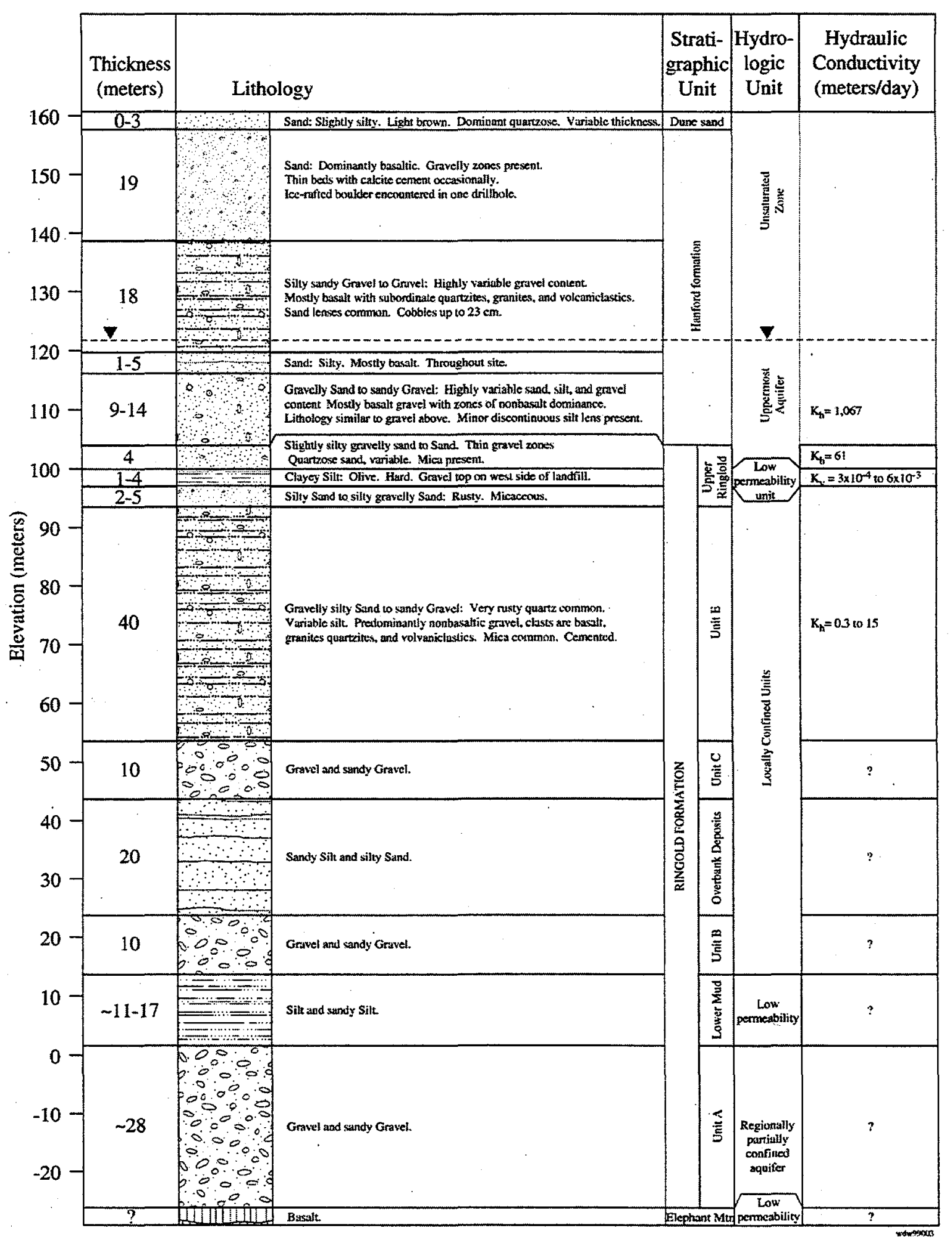

Figure 3.1. Stratigraphic Column at the NRDWL and Associated Hydrogeology 
The hydraulic gradient beneath NRDWL is very low (0.00005; Weekes et al. 1987) because the aquifer is very transmissive. Previous estimates based on data from the nearby wells indicate that flow is generally west to east (Weekes et al. 1987, p. 43). A water-table map of the region around the landfill is shown in Figure 3.2. Assuming groundwater flows perpendicular to the equipotential lines, flow converges from the north-northeast and the southwest, and moves toward the southeast. Contaminant plumes originating in the 200 East Area move through the area from northwest to southeast, corroborate this interpretation.

Two wells at NRDWL sample the bottom of the uppermost aquifer, i.e., just above the lowpermeability unit. Heads in these wells are virtually the same as in adjacent wells completed at the top of the aquifer, indicating no significant vertical gradient (Lindberg 1999, Section 3.7).

Water-levels beneath NRDWL declined nearly $2 \mathrm{~m}$ since 1988 because lower volumes of liquid waste are being discharged to the ground in the 200 Areas (Figure 3.3) (Lindberg 1999, Section 3.7). Based on a comparison of present levels of the water table with a hindcast water-table map (estimating water-table elevations in 1944, ERDA 1975) the water table could decline as much as $4.6 \mathrm{~m}$ before returning to preHanford Site levels.

\subsection{Summary of Groundwater Monitoring Results}

Monitoring began at NRDWL and adjacent Solid Waste Landfill in 1987. Wells were sampled . quarterly in 1987 through 1989 , and semiannually thereafter. Some of the wells are co-sampled with Hanford environmental surveillance monitoring.

Concentrations of RCRA indicator parameters (specific conductance, $\mathrm{pH}$, total organic carbon, and total organic halogens) have not significantly increased (or $\mathrm{pH}$ decreased) over background (upgradient) concentrations. Some chlorinated hydrocarbons were detected in the NRDWL monitoring wells in concentrations below their maximum contaminant levels (Table 3.1). One potential source of these low levels of chlorinated hydrocarbons is vadose-zone transport from the adjacent Solid Waste Landfill. Chlorinated hydrocarbons were disposed at the Solid Waste Landfill and are detected in groundwater downgradient of the Solid Waste Landfill. Soil gas surveys at NRDWL have detected several volatile organic compounds including chlorinated hydrocarbons. However, the shallow nature of soil gas surveys to date makes it inappropriate to link chlorinated hydrocarbons disposed at the Solid Waste Landfill with the low levels of chlorinated hydrocarbons detected in the groundwater (Jacques and Kerkow 1993).

Vadose zone gases were sampled during installation of wells 699-26-33 and 699-25-34A in 1992 (Hodges 1993a). A chlorinated hydrocarbon, probably carbon tetrachloride, was detected as deep as $37 \mathrm{~m}$, near the water table (a malfunctioning gas chromatograph prevented unique identification of the compound). A shallow vadose zone soil gas survey was conducted in 1993 (Hodges 1994). The survey found widespread acetone and several chlorinated hydrocarbons, most notably tetrachloroethylene and trichloroethylene. The highest concentrations were detected over the older chemical trenches near the east end of NRDWL. Carbon tetrachloride, 1,1,1-trichloroethane, and chloroform were also detected locally. The presence of chlorinated hydrocarbons in the vadose zone suggests the possibility of their migration from the NRDWL to groundwater, and in fact most of them have been detected in groundwater. 


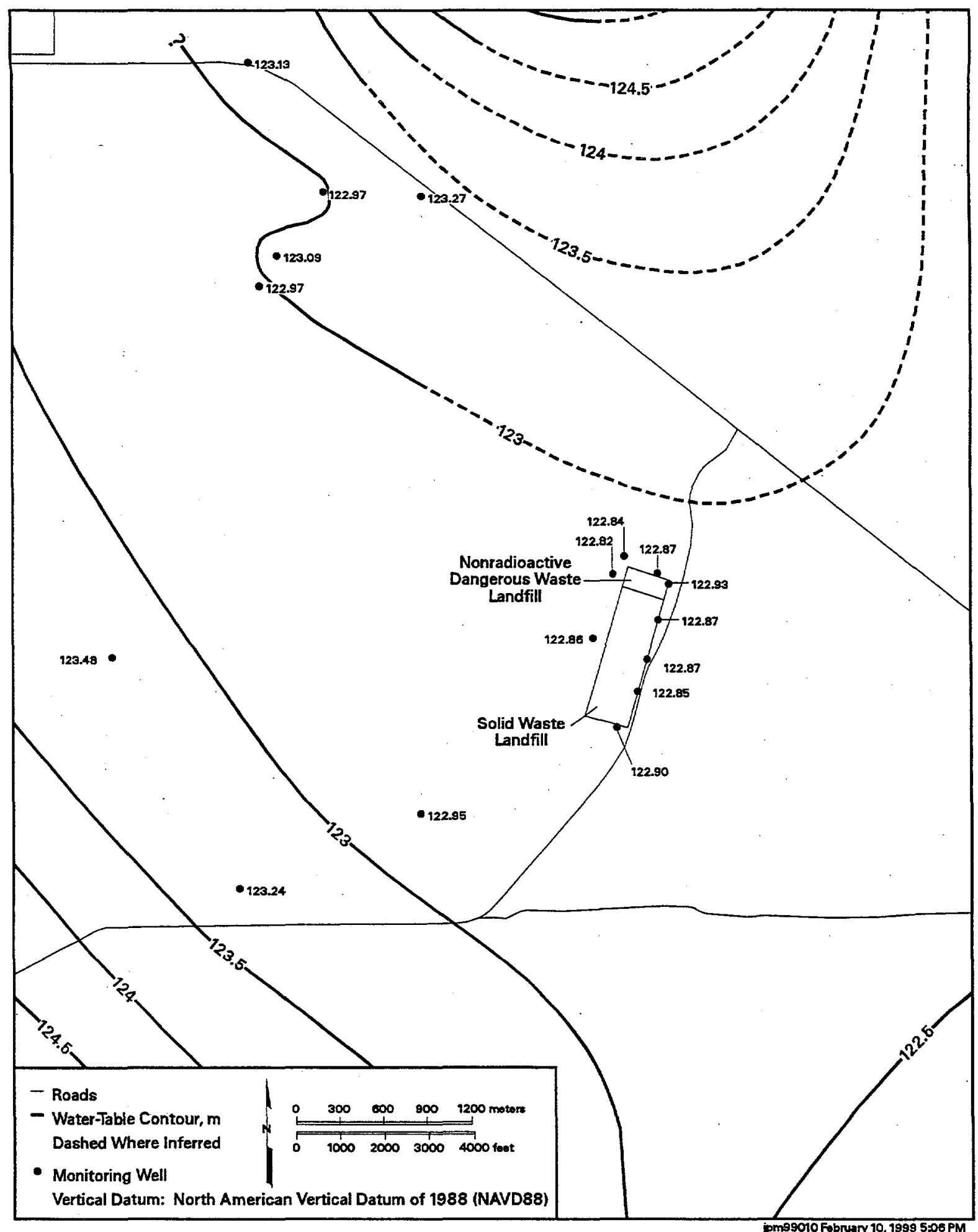

Figure 3.2. Water-Table Map for Nonradioactive Dangerous Waste Landfill and Solid Waste Landfill, June 1998 


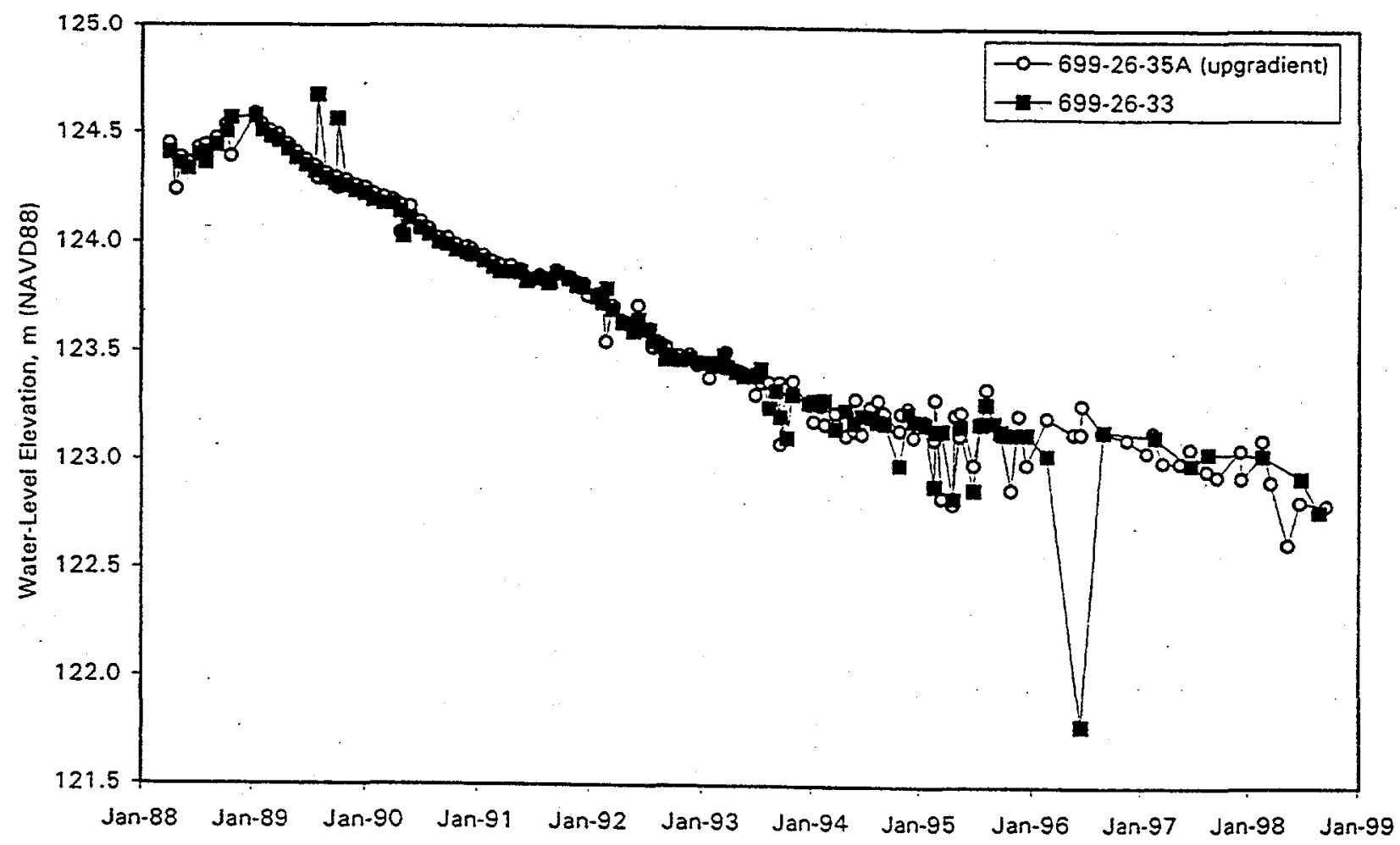

Figure 3.3. Water-Table Elevations in Wells Monitoring Nonradioactive Dangerous Waste Landfill

Tetrachloroethylene concentrations are higher in downgradient wells 699-25-34A and 699-25-34B than in upgradient wells (Figure 3.4). Downgradient concentrations are fairly steady at 1 to $2 \mu \mathrm{g} / \mathrm{L}$. Trichloroethylene concentrations are also slightly higher in downgradient wells (Figure 3.5), but concentrations are less than or equal to $1 \mu \mathrm{g} / \mathrm{L}$.

Carbon tetrachloride and 1,1,1-trichloroethane were detected in upgradient and downgradient NRDWL wells. All of the concentrations were less than or equal to $2 \mu \mathrm{g} / \mathrm{L}$, and most are less than $1 \mu \mathrm{g} / \mathrm{L}$ (Figures 3.6 and 3.7). Concentrations in the early 1990s were greater in downgradient wells 699-25-34A and 699-25-34B than in upgradient wells. Since then, concentrations have decreased and are approximately the same as in upgradient wells.

Chloroform was detected in downgradient wells. Recently concentrations have increased from below detection limits to $1 \mu \mathrm{g} / \mathrm{L}$ in upgradient wells, which is greater than in downgradient wells (Figure 3.8). The cause of this change in upgradient concentrations is not known.

As mentioned previously in this section, acetone was also detected in shallow vadose zone gases. One set of samples from the NRDWL wells was analyzed for acetone in 1990. All results were below detection limits.

Groundwater beneath the NRDWL is contaminated with tritium, iodine-129, and nitrate from the 200 Areas. The plume boundaries bisect the Central Landfill, with low concentrations to the southwest and high concentrations to the northeast. Concentrations of these constituents in groundwater are decreasing gradually with time in all of the shallow NRDWL wells. 
Table 3.1. Range and Average Concentration of Detected Chlorinated Hydrocarbons in NRDWL Wells, 1987-1998 (a)

\begin{tabular}{|c|c|c|c|c|c|}
\hline Well & Constituent & $\begin{array}{c}\text { Minimum } \\
\mu g / L\end{array}$ & $\begin{array}{c}\text { Maximum } \\
\mu \mathrm{g} / \mathrm{L}\end{array}$ & $\begin{array}{c}\text { Average }^{(b)} \\
\mu g / L\end{array}$ & $\begin{array}{l}\text { Number of } \\
\text { Sample } \\
\text { Dates }\end{array}$ \\
\hline \multirow{9}{*}{$\begin{array}{l}699-26-34 \mathrm{~A} \\
\text { upgradient }\end{array}$} & 1,1,1-Trichloroethane & $\angle \mathrm{DL}$ & 2.10 & 0.85 & 20 \\
\hline & 1,1-Dichloroethane & $\overline{\mathrm{DL}}$ & 0.14 & 0.01 & 20 \\
\hline & 1,4-Dichlorobenzene & $\overline{\mathrm{DL}}$ & 0.09 & 0.01 & 20 \\
\hline & Carbon tetrachloride & $<\mathrm{DL}$ & 0.91 & 0.12 & 20 \\
\hline & Chloroform & $\angle \mathrm{DL}$ & 1.0 & 0.07 & 20 \\
\hline & Tetrachloroethylene & $<\mathrm{DL}$ & 0.70 & 0.26 & 20 \\
\hline & Trichloroethylene & $<\mathrm{DL}$ & 0.46 & 0.11 & 19 \\
\hline & TOC & $<\mathrm{DL}$ & 635.85 & 169.11 & 14 \\
\hline & TOX & $<\mathrm{DL}$ & 3.75 & 0.83 & 22 \\
\hline \multirow{9}{*}{$\begin{array}{l}699-26-35 \mathrm{~A} \\
\text { upgradient }\end{array}$} & 1,1,1-Trichloroethane & $\overline{\mathrm{DL}}$ & 4.0 & 1.25 & 36 \\
\hline & 1,1-Dichloroethane & $<\mathrm{DL}$ & 0.30 & 0.02 & 36 \\
\hline & 1,4-Dichlorobenzene & $\overline{\mathrm{DL}}$ & 0.05 & $<\mathrm{DL}$ & 32 \\
\hline & Carbon tetrachloride & $\angle \mathrm{DL}$ & 2.0 & 0.19 & 37 \\
\hline & Chloroform & $<\mathrm{DL}$ & 1.0 & 0.06 & 37 \\
\hline & Tetrachloroethylene & $\angle \mathrm{DL}$ & 3.0 & 0.46 & 36 \\
\hline & Trichloroethylene & $<\mathrm{DL}$ & 1.0 & 0.16 & 35 \\
\hline & TOC & $\angle \mathrm{DL}$ & 933 & 95 & 43 \\
\hline & TOX & $<\mathrm{DL}$ & 9.8 & 2.1 & 32 \\
\hline \multirow{9}{*}{$\begin{array}{l}\text { 699-25-34A } \\
\text { downgradient }\end{array}$} & 1,1,1-Trichloroethane & $\angle \mathrm{DL}$ & 6.1 & 2.04 & 21 . \\
\hline & 1,1-Dichloroethane & $<\mathrm{DL}$ & 0.3 & 0.05 & 21 \\
\hline & 1,4-Dichlorobenzene & $\angle \mathrm{DL}$ & 0.06 & $<\mathrm{DL}$ & 17 \\
\hline & Carbon tetrachloride & $\angle \mathrm{DL}$ & 1.6 & 0.25 & 22 \\
\hline & Chloroform & $\angle D L$ & 0.5 & 0.15 & 22 \\
\hline & Tetrachloroethylene & $\angle D L$ & 1.5 & 0.77 & 21 \\
\hline & Trichloroethylene & $<\mathrm{DL}$ & 0.7 & 0.28 & 20 \\
\hline & TOC & $\angle \mathrm{DL}$ & 770 & 90 & 28 \\
\hline & TOX & $\angle \mathrm{DL}$ & 10.7 & 2.4 & 23 \\
\hline \multirow{9}{*}{$\begin{array}{l}\text { 699-25-34B } \\
\text { downgradient }\end{array}$} & 1,1,1-Trichloroethane & $\angle \mathrm{DL}$ & 7.0 & 1.72 & 21 \\
\hline & 1,1-Dichloroethane & $\angle \mathrm{DL}$ & 0.3 & 0.06 & 21 \\
\hline & 1,4-Dichlorobenzene & $\angle \mathrm{DL}$ & 0.28 & 0.03 & 17 \\
\hline & Carbon tetrachloride & $\angle \mathrm{DL}$ & 0.89 & 0.14 & 22 \\
\hline & Chloroform & $\angle \mathrm{DL}$ & 1.1 & 0.16 & 22 \\
\hline & Tetrachloroethylene & $\angle \mathrm{DL}$ & 1.75 & 0.69 & 21 \\
\hline & Trichloroethylene & $\angle \mathrm{DL}$ & 1.1 & 0.3 & 20 \\
\hline & TOC & $\angle \mathrm{DL}$ & 800 & 89 & 28 \\
\hline & TOX & $<\mathrm{DL}$ & 16.2 & 3.6 & 23 \\
\hline \multirow{4}{*}{$\begin{array}{l}\text { 699-25-34D } \\
\text { downgradient }\end{array}$} & 1,1,1-Trichloroethane & 0.7 & 6.0 & 2.1 & 13 \\
\hline & 1,1-Dichloroethane & $\angle \mathrm{DL}$ & 2.0 & 0.22 & 13 \\
\hline & 1,4-Dichlorobenzene & $<\mathrm{DL}$ & $\overline{0.4}$ & 0.03 & 13 \\
\hline & Carbon tetrachloride & $<\mathrm{DL}$ & 0.89 & 0.26 & 14 \\
\hline
\end{tabular}


Table 3.1. (contd)

\begin{tabular}{|c|c|c|c|c|c|}
\hline Well & Constituent & $\underset{\mu \mathrm{g} / \mathrm{L}}{\operatorname{Minimum}}$ & $\begin{array}{c}\text { Maximum } \\
\mu \mathrm{g} / \mathrm{L}\end{array}$ & $\begin{array}{c}\text { Average }^{(b)} \\
\mu \mathrm{g} / \mathrm{L}\end{array}$ & $\begin{array}{l}\text { Number of } \\
\text { Sample } \\
\text { Dates }\end{array}$ \\
\hline & Chloroform & $\overline{\angle \mathrm{DL}}$ & 0.33 & $\overline{0.13}$ & $\overline{14}$ \\
\hline & Tetrachloroethylene & $<\mathrm{DL}$ & 2.0 & 0.87 & 13 \\
\hline & Trichloroethylene & $<\mathrm{DL}$ & 0.90 & $\overline{0.48}$ & 12 \\
\hline & TOC & $<\mathrm{DL}$ & 575 & 131 & 14 \\
\hline & TOX & $\angle \mathrm{DL}$ & 11.6 & 4.8 & 9 \\
\hline \multirow{9}{*}{$\begin{array}{l}\text { 699-26-33 } \\
\text { downgradient }\end{array}$} & 1,1,1-Trichloroethane & $<\mathrm{DL}$ & 2.6 & 1.05 & 21 \\
\hline & 1,1-Dichloroethane & $<\mathrm{DL}$ & 0.13 & 0.01 & 21 \\
\hline & 1,4-Dichlorobenzene & $<\mathrm{DL}$ & $<\mathrm{DL}$ & $<\mathrm{DL}$ & 17 \\
\hline & Carbon tetrachloride & $\angle \mathrm{DL}$ & 1.9 & 0.22 & 21 \\
\hline & Chloroform & $<\mathrm{DL}$ & 0.30 & 0.06 & 21 \\
\hline & Tetrachloroethylene & $<\mathrm{DL}$ & 0.92 & 0.40 & 21 \\
\hline & Trichloroethylene & $<\mathrm{DL}$ & 0.52 & 0.14 & 20 \\
\hline & TOC & $<\mathrm{DL}$ & 1470 & 160 & 28 \\
\hline & TOX & $\angle \mathrm{DL}$ & 13 & 2.2 & 23 \\
\hline \multirow{9}{*}{$\begin{array}{l}\text { 699-26-34B } \\
\text { downgradient }\end{array}$} & 1,1,1-Trichloroethane & 0.24 & 1.4 & 0.99 & 13 \\
\hline & 1,1-Dichloroethane & <DL & 0.07 & 0.01 & 13 \\
\hline & 1,4-Dichlorobenzene & $\angle \mathrm{DL}$ & $<\mathrm{DL}$ & $<\mathrm{DL}$ & $\overline{13}$ \\
\hline & Carbon tetrachloride & $<\mathrm{DL}$ & 0.60 & 0.18 & 13 \\
\hline & Chloroform & $<\mathrm{DL}$ & 0.20 & 0.05 & $\overline{13}$ \\
\hline & Tetrachloroethylene & $<\mathrm{DL}$ & 0.82 & 0.35 & 13 \\
\hline & Trichloroethylene & $<\mathrm{DL}$ & 0.34 & 0.13 & 12 \\
\hline & TOC & $\angle \mathrm{DL}$ & 636 & 169 & 14 \\
\hline & TOX & $<\mathrm{DL}$ & 8.0 & 3.3 & 9 \\
\hline \multirow{9}{*}{$\begin{array}{l}\text { 699-26-35C } \\
\text { upgradient, deep }\end{array}$} & 1,1,1-Trichloroethane & $<\mathrm{DL}$ & $\angle \overline{D L}$ & $<\mathrm{DL}$ & 21 \\
\hline & 1,1-Dichloroethane & $<\mathrm{DL}$ & $<\mathrm{DL}$ & $<\mathrm{DL}$ & 21 \\
\hline & 1,4-Dichlorobenzene & $<\mathrm{DL}$ & $<\overline{D L}$ & $<\mathrm{DL}$ & 17 \\
\hline & Carbon tetrachloride & $<\overline{D L}$ & $<\mathrm{DL}$ & $<\mathrm{DL}$ & 21 \\
\hline & Chloroform & $\angle \overline{D L}$ & 0.20 & 0.02 & 21 \\
\hline & Tetrachloroethylene & $\angle \mathrm{DL}$ & $<\mathrm{DL}$ & $<\overline{D L}$ & 21 \\
\hline & Trichloroethylene & $\angle \mathrm{DL}$ & 0.07 & $<\mathrm{DL}$ & 20 \\
\hline & TOC & $\angle \mathrm{DL}$ & 203 & 32 & 27 \\
\hline & TOX & $<\mathrm{DL}$ & 9.8 & 1.2 & 21 \\
\hline \multirow{9}{*}{$\begin{array}{l}\text { 699-25-33A } \\
\text { downgradient, } \\
\text { deep }\end{array}$} & 1,1,1-Trichloroethane & $<\mathrm{DL}$ & 0.25 & 0.02 & 21 \\
\hline & 1,1-Dichloroethane & $\langle\mathrm{DL}$ & $<\mathrm{DL}$ & $\overline{\mathrm{DL}}$ & 21 \\
\hline & 1,4-Dichlorobenzene & <DL & $<\mathrm{DL}$ & $<\overline{\mathrm{DL}}$ & 17 \\
\hline & Carbon tetrachloride & $\angle \mathrm{DL}$ & $<\mathrm{DL}$ & $\angle \mathrm{DL}$ & 22 \\
\hline & Chloroform & $<\mathrm{DL}$ & $<\overline{D L}$ & $<\overline{D L}$ & 22 \\
\hline & Tetrachloroethylene & $\angle \mathrm{DL}$ & 0.06 & $<\mathrm{DL}$ & 21 \\
\hline & Trichloroethylene & $\angle \mathrm{DL}$ & $<\mathrm{DL}$ & $<\mathrm{DL}$ & 20 \\
\hline & TOC & $\angle \mathrm{DL}$ & 1320 & 126 & 27 \\
\hline & TOX & $\angle \mathrm{DL}$ & 6.4 & 0.87 & 22 \\
\hline \multicolumn{6}{|c|}{$\begin{array}{l}\text { (a) Excluded data flagged } \\
\text { (b) Changed less-than det } \\
\text { DL = detection level } \\
\text { TOC = total organic carbon. } \\
\text { TOX = total organic halogen. }\end{array}$} \\
\hline
\end{tabular}




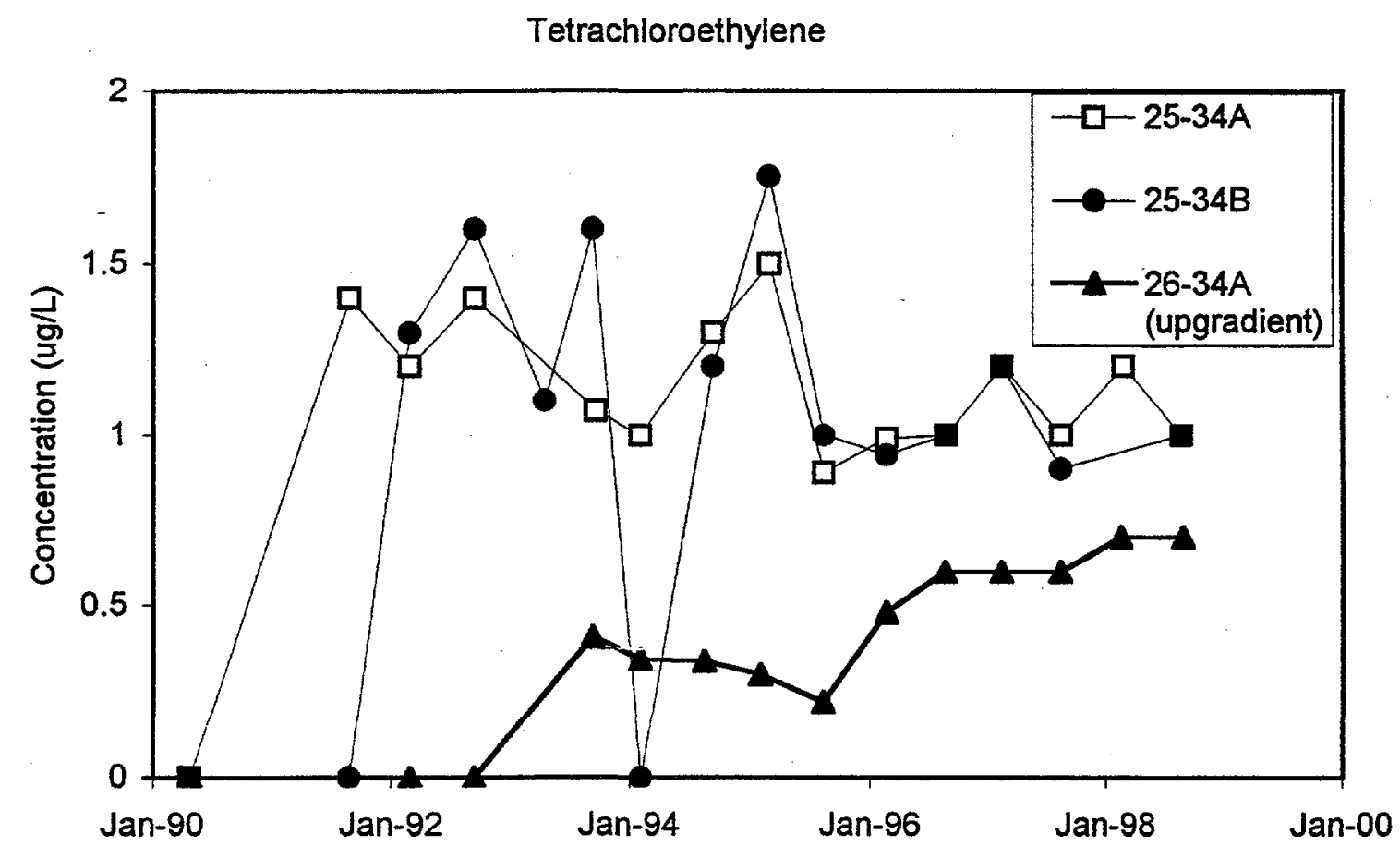

Figure 3.4. Tetrachloroethene Concentrations in NRDWL Wells

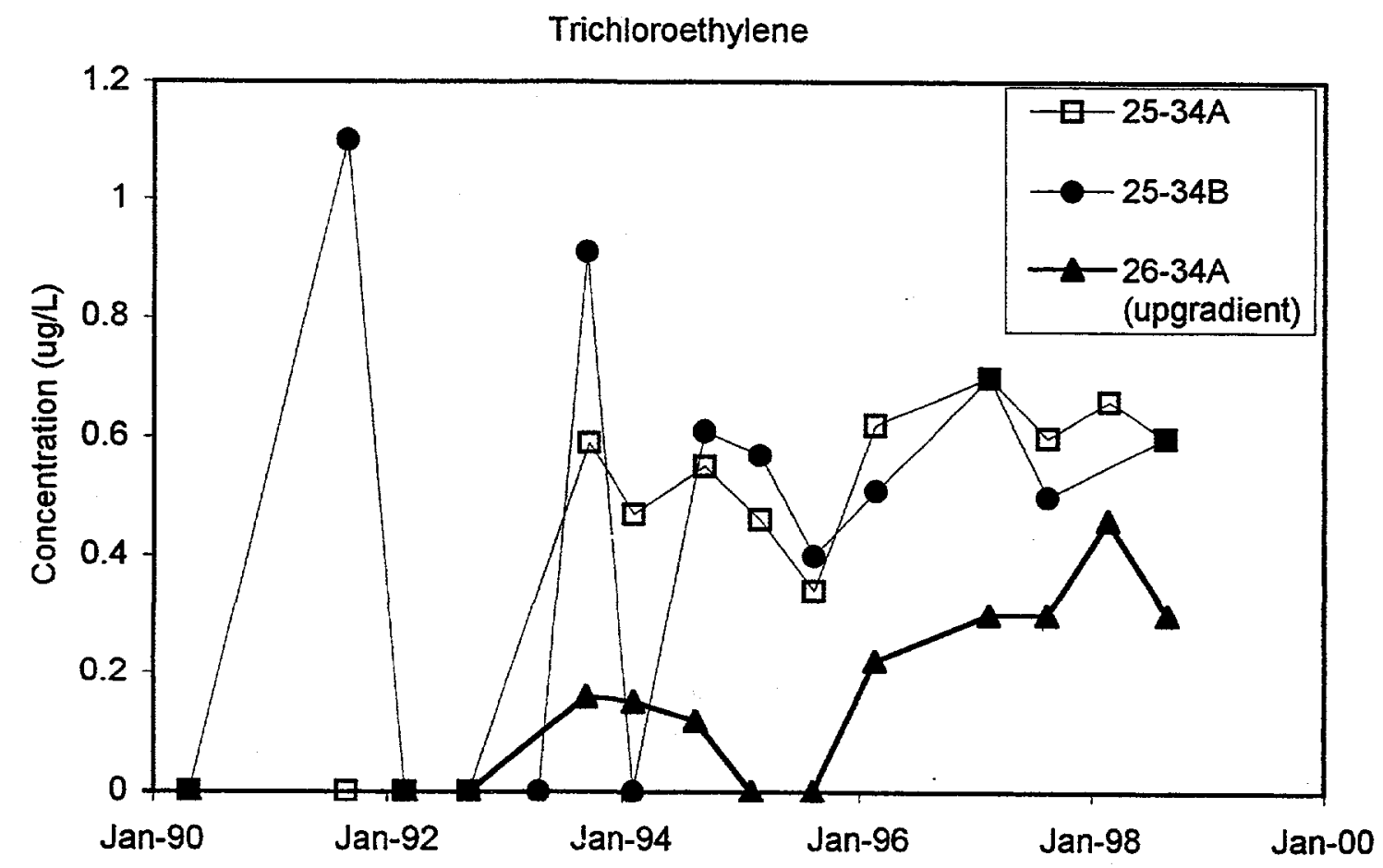

Figure 3.5. Trichloroethene Concentrations in NRDWL Wells 


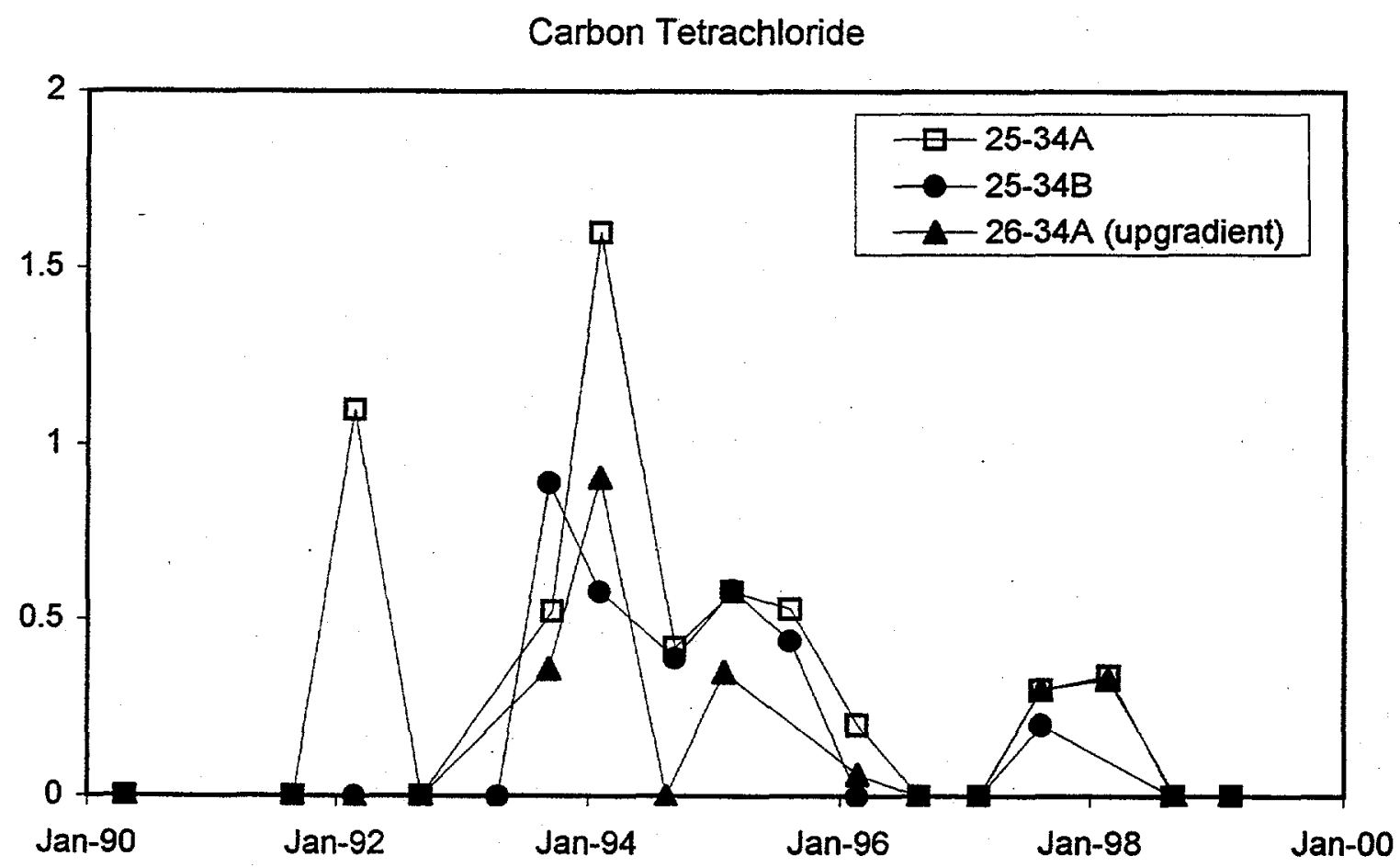

Figure 3.6. Carbon Tetrachloride Concentrations at NRDWL Wells

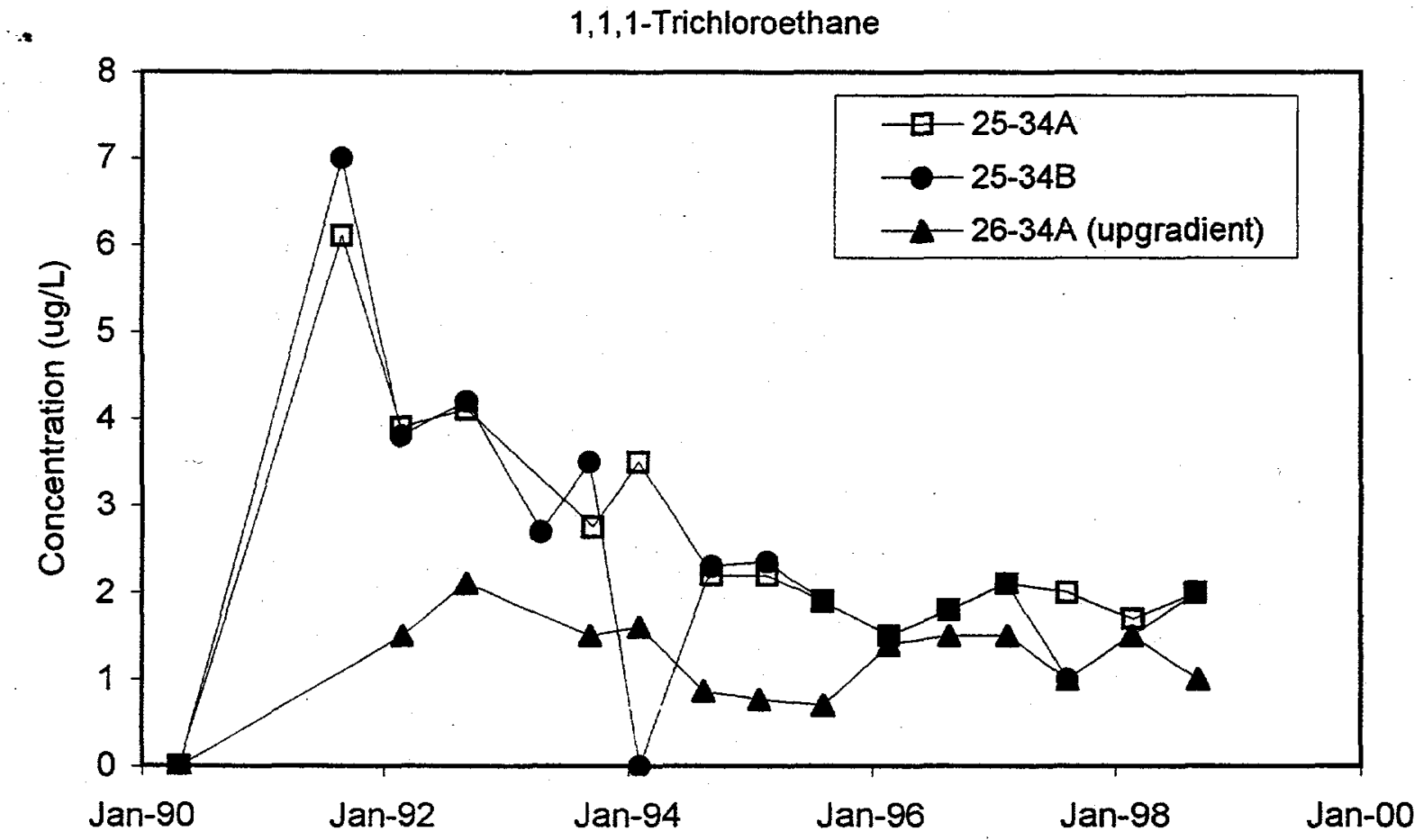

Figure 3.7. 1,1,1-Trichloroethane Concentrations at NRDWL Wells 


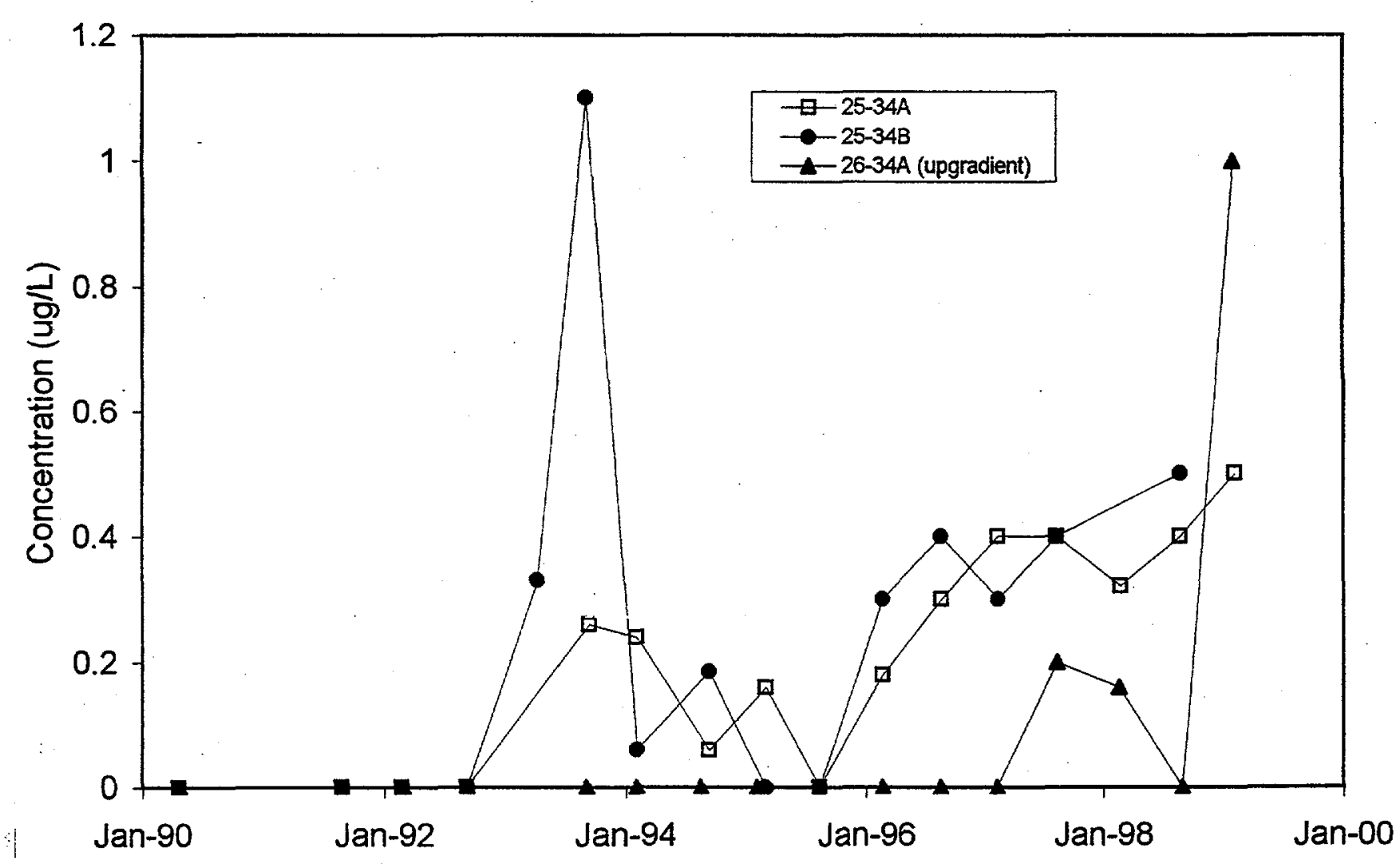

Figure 3.8. Chloroform Concentrations in NRDWL Wells 


\subsection{Conceptual Model}

The following characteristics constitute key portions of the NRDWL conceptual model:

- Relatively small quantities of dangerous waste liquids were disposed of in NRDWL; most were placed in sorbing material so not much free liquid remained. It is unlikely that dense, nonaqueous phase liquids are present.

- Chlorinated hydrocarbons are present in vadose vapors and are the primary contaminant of concern for groundwater.

- Natural precipitation may carry some contaminants through the vadose zone to groundwater.

- Dangerous waste materials remain in the landfill; therefore, contamination from the landfill may still impact groundwater.

- Contaminants may move laterally within the vadose zone via vapor transport, perhaps from the adjacent solid waste landfill. However, soil gas studies to date have failed to prove this.

- Contaminants remain in the uppermost aquifer above the low-permeability unit. To date, indicator parameters measured in downgradient wells at the water table are lower in concentration than critical means or are within critical ranges, and contaminant concentrations are below respective MCLs. Similarly, the downgradient well sampling groundwater at the top of the low-permeability unit (well 699-25-33A) has very low concentrations of constituents monitored.

- The zone below the low-permeability unit has not been impacted by NRDWL because the saturated zone above the unit has not been impacted adversely by the NRDWL. That is, in order for the lower zone to be affected, the upper one must be affected first.

- Regionally, groundwater flows toward the southeast; however, flow directly beneath to the landfill may be toward the east or even northeast. The hydraulic gradient in the immediate vicinity of NRDWL is extremely low. 


\subsection{Groundwater Monitoring Program}

\subsection{Objectives of RCRA Monitoring}

The overall objectives of the Groundwater Monitoring Program at the Hanford Site are to (a) protect human health and the environment; (b) comply with governmental regulations; and (c) contribute to groundwater investigation or remediation. Specifically, the objective of the groundwater monitoring at NRDWL is to detect adverse impact from the facility on the groundwater quality.

\subsection{Special Conditions}

Two hydrogeological conditions at NRDWL are of special concern to the development of this groundwater monitoring plan. The first is the low-permeability unit within Upper Ringold unit or Ringold Formation unit $E$. This low-permeability layer limits the thickness of the uppermost aquifer locally to about $22 \mathrm{~m}$. It also limits the depth of contaminant sinkers (e.g., dense, nonaqueous phase liquids). A groundwater monitoring plan must account for this low-permeability zone and provide assurance that groundwater contamination from NRDWL has not reached the top of the low-permeability unit, as well as more shallow depths of the uppermost aquifer. (See also Section 4.0, "Conceptual Model.")

The second special condition is the extremely low hydraulic gradient and the difficulty in determining an accurate direction of groundwater flow in the uppermost aquifer. Water-table maps (like in Weekes et al. 1987, p. 43) indicate the flow should be generally from west to east in the immediate vicinity of the NRDWL. However, contaminate plumes like tritium from the 200 East Area are moving from the northwest to the southeast. (See also Section 4.0, "Conceptual Model.")

\subsection{Sampling and Analysis Plan}

\subsubsection{Monitoring Well Network}

The six downgradient wells and three upgradient wells (Table 5.1) of the monitoring well network are designed to

- detect groundwater contamination (from NRDWL) before it moves downgradient of the network wells

- compare upgradient and downgradient concentrations of indicator parameters

- determine if groundwater contamination has migrated vertically and impacted groundwater at the base of the uppermost aquifer (immediately above the low-permeability unit). 
Table 5.1. Monitoring Well Network

\begin{tabular}{|l|c|c|c|c|}
\hline \multicolumn{1}{|c|}{ Well } & Year Installed & \multicolumn{1}{|c|}{$\begin{array}{c}\text { Hydrogeologic Unit } \\
\text { Monitored }\end{array}$} & Well Construction Standard & $\begin{array}{c}\text { Upgradient/ } \\
\text { Downgradient }\end{array}$ \\
\hline \hline 699-25-33A & 1987 & Top of LPU(a) & WAC 173-160 & Downgradient \\
\hline 699-25-34A & 1986 & Top of Unconfined Aquifer & WAC 173-160 & Downgradient \\
\hline 699-25-34B & 1986 & Top of Unconfined Aquifer & WAC 173-160 & Downgradient \\
\hline 699-25-34D & 1992 & Top of Unconfined Aquifer & WAC 173-160 & Downgradient \\
\hline 699-26-33 & 1986 & Top of Unconfined Aquifer & WAC 173-160 & Downgradient \\
\hline 699-26-34A & 1986 & Top of Unconfined Aquifer & WAC 173-160 & Upgradient \\
\hline 699-26-34B & 1992 & Top of Unconfined Aquifer & WAC 173-160 & Downgradient \\
\hline 699-26-35A (b) $^{\text {(a) }}$ & 1986 & Top of Unconfined Aquifer & WAC 173-160 & Upgradient \\
\hline 699-26-35C & 1987 & Top of LPU & WAC 173-160 & Upgradient \\
\hline $\begin{array}{l}\text { (a) Low-permeability unit in Upper Ringold Formation. } \\
\text { (b) Well shared with Solid Waste Landfill Network. }\end{array}$ & & \\
\hline
\end{tabular}

The six downgradient wells are located (Figure 5.1) around the northern, eastern, and southern boundaries of NRDWL to detect potentially contaminated groundwater in response to groundwater flowing either eastward (interpreted from water table contours) or southeastward (interpreted from plume maps). Monitoring Efficiency Model (MEMO) results demonstrate that the downgradient wells have a monitoring efficiency of more than $90 \%$ for flow directions from 80 degrees to 140 degrees clockwise from north (DOE 1990). Results for a flow direction of 125 degrees clockwise from due north (southeast-the most likely flow direction) indicate a model efficiency of $99.8 \%$. One downgradient well (699-25-33A) was installed at the top of the low-permeability unit to detect potentially contaminated groundwater at the base of the uppermost aquifer.

The three upgradient wells (Figure 5.1) are located northwestward to determine background water quality. Wells 699-26-34A and 699-26-35A are screened near the water table and are compared with downgradient water quality (from five downgradient wells) to determine if NRDWL has adversely affected groundwater quality. (See Sections 6.2 and 6.3 for an explanation of the methods used to compare background and downgradient water quality. Well 699-26-35A is shared with the Solid Waste Landfill.) Well 699-26-35C is screened immediately above the low-permeability zone, and results are used for information purposes only. Results from this well cannot be used for background statistics because the well monitors a different portion of the aquifer.

To determine whether groundwater contamination can be detected lower in the aquifer (lower than near the water table), two deeper wells sample groundwater at the top of the low-permeability zone. One of the deeper wells is located upgradient of NRDWL and the other is downgradient to examine upgradient and downgradient concentrations of chlorinated hydrocarbons over time (Figure 5.1). Some chlorinated hydrocarbons have a dense nonaqueous phase that could migrate downward to the top of the lowpermeability zone.

Appendix A contains construction details for each well in the groundwater monitoring network at NRDWL. 


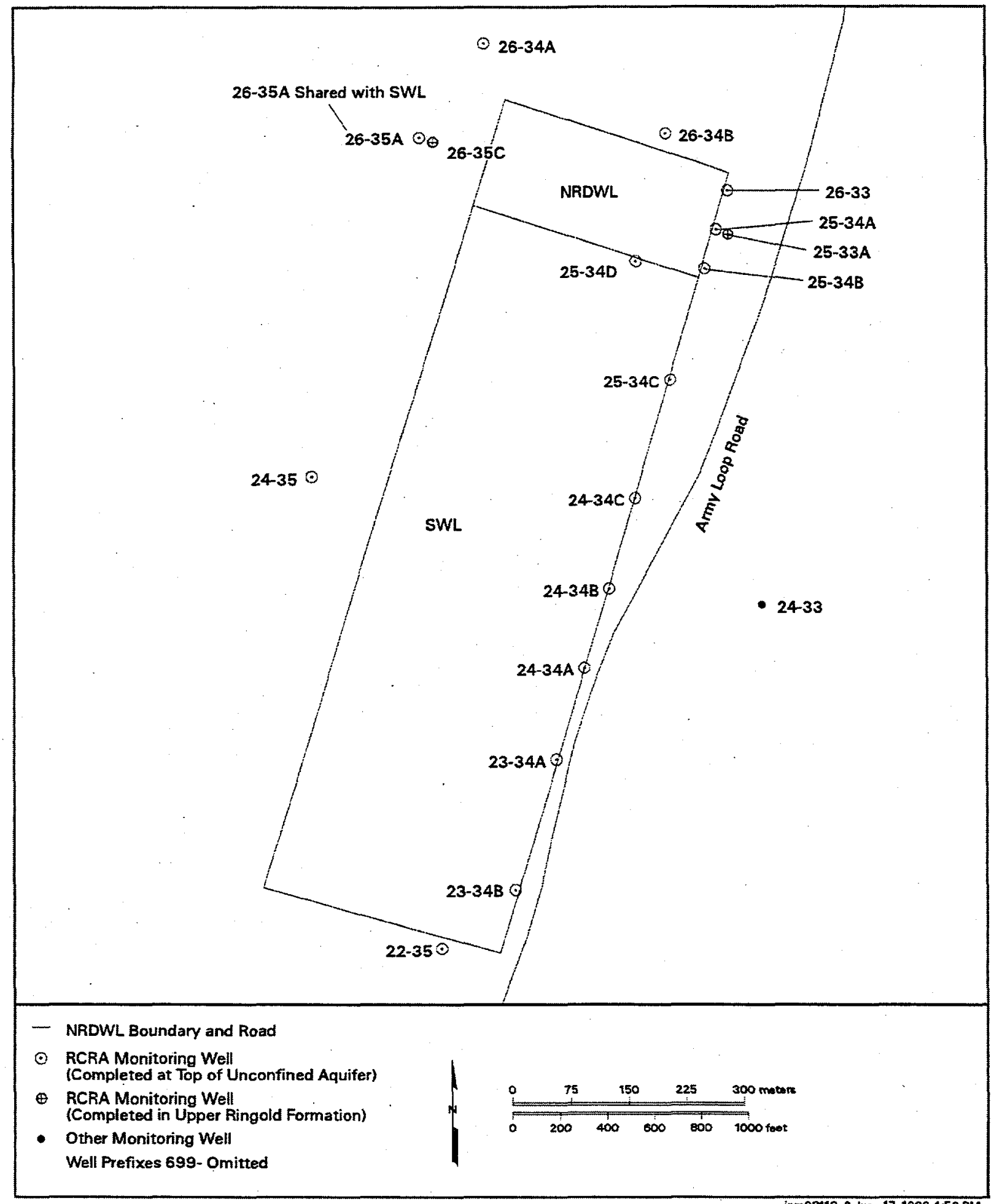

Figure 5.1. Monitoring Well Locations for Solid Waste Landfill and Nonradioactive Dangerous Waste Landfill 


\subsubsection{Constituent List and Sampling Frequency}

After the first year, groundwater beneath RCRA treatment, storage, and disposal units in an interim status/indicator-evaluation program (WAC 173-303 and by reference, 40 CFR 265) must be monitored for groundwater quality parameters and contaminant indicator parameters. If appropriate, site-specific parameters may be added (Table 5.2 lists the monitored constituents and frequencies appropriate for NRDWL). The groundwater quality parameters are to be monitored annually, the contaminant indicator parameters semiannually, and the site-specific parameters semiannually. Groundwater quality parameters include chloride, iron, manganese, phenols, sodium, and sulfate. Contaminant indicator parameters include specific conductance, $\mathrm{pH}$, total organic carbon, and total organic halogens. Appropriate sitespecific parameters are nitrate and volatile chlorinated hydrocarbons. Nitrate is monitored semiannually because it is a significant upgradient groundwater contaminant that may affect an indicator parameter (specific conductance). Volatile chlorinated hydrocarbons are monitored semiannually because they have been detected in the 12 years of groundwater monitoring at NRDWL.

\subsubsection{Determination of Groundwater Flow}

Depth-to-water measurements will continue to be collected from each monitoring well when each is sampled. Therefore, depth-to-water will be measured at least semiannually at all network wells. These depth-to-water measurements will be used to construct water-table maps which, in turn, will be reevaluated annually to determine the direction of groundwater flow beneath NRDWL. In addition, depth-towater will be measured at approximately six of the NRDWL monitoring wells during the month of March to support the efforts to make a water-table map of the entire Hanford Site for Hanford Site Groundwater Monitoring (Hartman 1999) each year. (Initially, the six wells measured will include 699-22-35, -23$34 \mathrm{~A},-25-34 \mathrm{C},-26-34 \mathrm{~A},-26-34 \mathrm{~B}$, and $-26-35 \mathrm{~A}$, but these may change as the needs of the Hanford Site map change.)

Table 5.2. Constituent List and Sampling Frequency

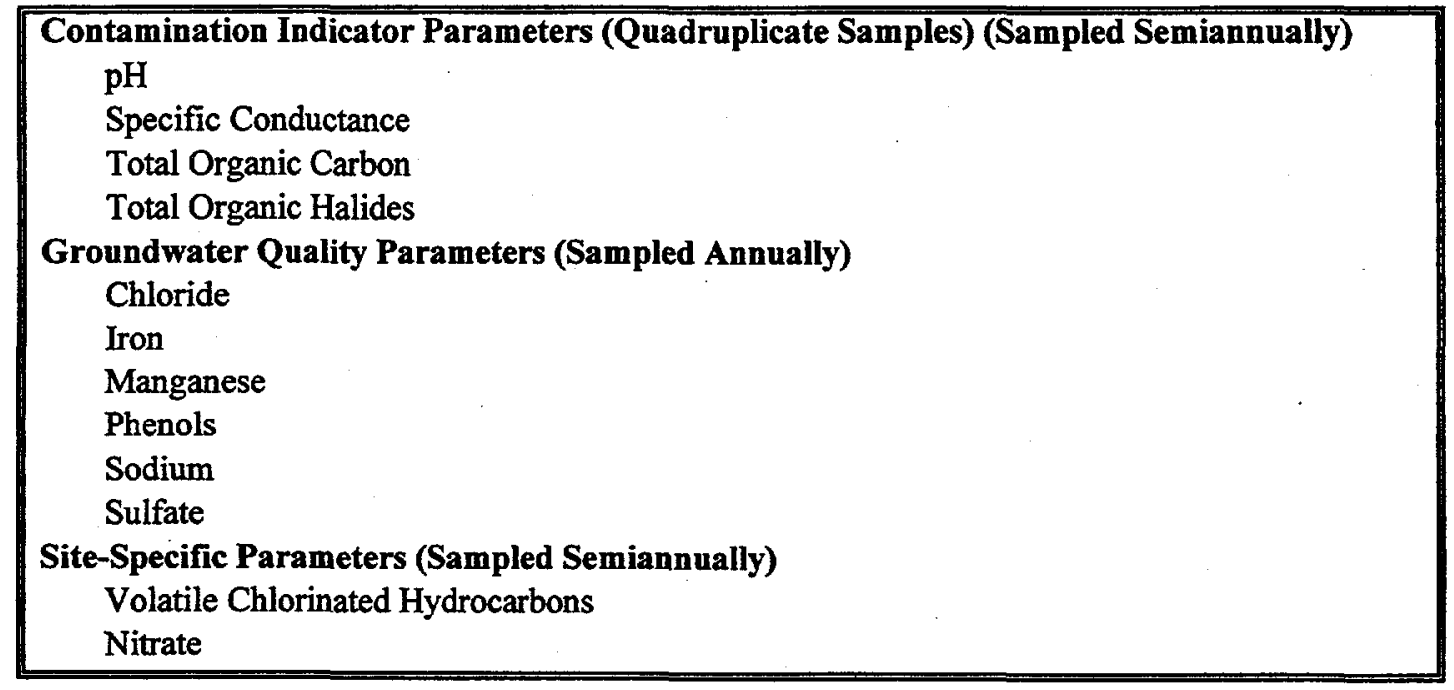


The water table at NRDWL has a very low gradient. Water-table maps constructed previously from the depth-to-water measurements (and surveyed elevation of the ground surface and casing top at each well) show that the gradient across the site is approximately 0.00005 (Weekes et al. 1987). Determining groundwater flow direction in an area the size of the NRDWL when the gradient is 0.00005 is very difficult. Very small errors in depth-to-water measurements or in surveyed casing elevations are significantly large compared to the low gradient. Therefore, maps showing the major plumes of tritium, nitrate, and iodine-129 will be used to corroborate flow directions based on water-table maps.

Using the Darcy equation,

$$
v=\frac{K(i)}{n_{(e)}}
$$

average groundwater flow rate ( $v$ ) will be estimated from known estimates of hydraulic conductivity (K), the water-table gradient (i), and effective porosity $\left(\mathrm{n}_{(e)}\right)$.

\subsubsection{Sampling and Analysis Protocol}

Monitoring at NRDWL is part of the Hanford Groundwater Monitoring Project. Procedures for groundwater sampling, documentation, sample preservation, shipment, and chain-of-custody requirements are described in Pacific Northwest National Laboratory or subcontractor manuals (currently, Waste Management Northwest procedures manual ES-SSPM-001, Waste Management Federal Services, 1998) and in the groundwater monitoring quality assurance (QA) plan (PNNL 1998). Samples generally are collected after three casing volumes of water have been purged from the well or after field parameters (pH, temperature, specific conductance, and turbidity) have stabilized. For routine groundwater samples, preservatives are added to the collection bottles before their use in the field. Samples to be analyzed for metals are usually filtered in the field so that results represent dissolved metals.

Procedures for field measurements are specified in the subcontractor's or manufacturer's manuals. Analytical methods are specified in contracts with laboratories, and most are standard methods from Test Methods for Evaluating Solid Wastes, Physical/Chemical Methods (EPA 1986b). Analytical methods are described in Gillespie (1999). Alternative procedures meet the guidelines of SW-846, Chapter 10 (EPA 1979).

\subsubsection{Quality Assurance and Quality Control}

The QA and quality control (QC) program for groundwater monitoring is designed to assess and enhance the reliability and validity of groundwater data. The primary quantitative measures or parameters used to assess data quality are accuracy, precision, completeness, and the method detection limit. Qualitative measures include representativeness and comparability. Goals for data representativeness for groundwater monitoring projects are addressed qualitatively by the specification of well locations, well construction, sampling intervals, and sampling and analysis techniques in the groundwater monitoring plan for each RCRA facility. Comparability is the confidence with which one data set can be compared 
to another. The QC parameters are evaluated through laboratory checks (e.g., matrix spikes, laboratory blanks), replicate sampling and analysis, analysis of blind standards and blanks, and interlaboratory comparisons. Acceptance criteria have been established for each of these parameters (PNNL 1998), based on guidance from the U.S. Environmental Protection Agency (EPA 1986b). When a parameter is outside the criteria, corrective actions are taken to prevent a future occurrence and affected data are flagged in the database. 


\subsection{Data Management, Evaluation, and Reporting}

This section describes how groundwater data are stored, retrieved, evaluated, and interpreted. Statistical evaluation methods and reporting requirements are also described.

\subsection{Data Management}

The contract laboratories report analytical results electronically. The results are loaded into the Hanford Environmental Information System (HEIS) database. Field-measured parameters are entered manually or through electronic transfer. Data from HEIS may be downloaded to smaller databases, such as the Geosciences Data Analysis Toolkit (GeoDAT) for data validation, reduction, and trend analysis. Paper data reports and field records are considered to be the record copies and are stored at Pacific Northwest National Laboratory.

The data undergo a validation and verification process according to a documented procedure, as described in the project QA plan. QC data are evaluated against the criteria listed in the project QA plan and data flags are assigned when appropriate. In addition, data are screened by scientists familiar with the hydrogeology of the unit, compared to historical trends or spatial patterns, and flagged if they are not representative. Other checks on data may include comparison of general parameters to their specific counterparts (e.g., conductivity to ions; gross alpha to uranium), calculation of charge balances, and comparison of calculated versus measured conductivity. If necessary, the laboratory may be asked to check calculations or reanalyze the sample, or the well may be resampled.

\subsection{Interpretation}

After data are validated and verified, the acceptable data are used to interpret groundwater conditions at the site. Interpretive techniques include the following:

- Hydrographs: 'graph water levels versus time to determine decreases, increases, seasonal, or manmade fluctuations in groundwater levels.

- Water-table maps: use water-table elevations from multiple wells to construct contour maps to estimate flow directions. Groundwater flow is assumed to be perpendicular to lines of equal potential.

- Trend plots: graph concentrations of chemical or radiological constituents versus time to determine fluctuations and trends. These plots may be used in tandem with hydrographs and/or water-table maps to determine if concentrations relate to changes in water-level or in groundwater flow directions. 
- Plume maps: map distributions of chemical or radiological constituents areally in the aquifer to determine extent of contamination. Changes in plume distribution over time aid in determining movement of plumes and direction of flow.

\subsection{Statistical Evaluation}

The goal of RCRA detection monitoring is to determine if NRDWL has affected groundwater quality. This is determined based on the results of a statistical test. According to 40 CFR 265.92 [and by reference of WAC 173-303-400(3)], the owner/operator of an interim-status hazardous waste facility must establish initial background concentrations for the contamination indicator parameters: specific conductance, $\mathrm{pH}$, total organic carbon, and total organic halogen. Four replicate measurements for each parameter from each well were collected at NRDWL quarterly for 1 year. Data from the upgradient wells were used to determine the initial background arithmetic mean and variance.

Monitoring data collected after the first year are compared with the initial background data to determine if there is an indication that contamination may have occurred. A t-test is required to make this determination [ 40 CFR 265.93(b)]. A recommended method is the averaged replicate $t$-test method described in Appendix B of the RCRA Groundwater Monitoring Technical Enforcement Guidance Document (EPA 1986a). The averaged replicate t-test method for each contamination indicator parameter is calculated as:

$$
\mathrm{t}=\left(\overline{\mathrm{x}}_{\mathrm{i}}-\overline{\mathrm{x}}_{\mathrm{b}}\right) / \mathrm{S}_{\mathrm{b}} * \sqrt{1+1 / \mathrm{n}_{\mathrm{b}}}
$$

where $t=$ test statistic

$\bar{x}_{i}=$ average of replicates from the $i^{\text {th }}$ monitoring well

$\bar{x}_{\mathrm{b}}=$ background average

$S_{\mathrm{b}}=$ background standard deviation

$\mathrm{n}_{\mathrm{b}}=$ number of background replicate averages.

A test statistic larger than the Bonferroni critical value, $t_{c}$, (i.e., $t>t_{c}$ ) indicates a statistically significant probability of contamination. These Bonferroni critical values depend on the overall falsepositive rate required for each sampling period (i.e., $1 \%$ for interim status), the total number of wells in the monitoring network, and the number of degrees of freedom $\left(n_{b}-1\right)$ associated with the background standard deviation. Because of the nature of the test statistic in the above equation, results to be compared to background do not contribute to the estimate of the variance. The test can be reformulated, without prior knowledge of the results of the sample to be compared to background (i.e., $\bar{x}_{i}$ ), in such a way that a critical mean, $\mathrm{CM}$, can be obtained:

$$
\begin{aligned}
& \mathrm{CM}=\overline{\mathrm{x}}_{\mathrm{b}}+\mathrm{t}_{\mathrm{c}} * \mathrm{~S}_{\mathrm{b}} * \sqrt{\left(1+1 / \mathrm{n}_{\mathrm{b}}\right)} \text { (one tailed) } \\
& \mathrm{CM}=\overline{\mathrm{x}}_{\mathrm{b}} \pm \mathrm{t}_{\mathrm{c}} * \mathrm{~S}_{\mathrm{b}} * \sqrt{\left(1+1 / \mathrm{n}_{\mathrm{b}}\right)} \quad \text { (two tailed) }
\end{aligned}
$$


If downgradient data exceed the $\mathrm{CM}$, the data are determined to be statistically different from background. For $\mathrm{pH}$, a two-tailed CM (or critical range) is calculated and downgradient data beyond the range are considered to be statistically different from background. If a statistical exceedance is detected, the well will be resampled to determine if the originally detected increase (or $\mathrm{pH}$ decrease) was a result of laboratory or measurement error (verification sampling). If verification sampling confirms the exceedance, the owner/operator must notify the Washington State Department of Ecology within 7 days and submit a groundwater quality assessment plan within 15 days following the notification [ 40 CFR 265.93(d)]. The assessment monitoring program determines if dangerous waste or dangerous waste constituents from the facility have entered the groundwater, their concentration, and their rate and extent of migration [40 CFR 265.93(d)]. Critical mean values for the NRDWL are presented in Table 6.1.

\subsection{Reporting}

Chemistry and water-level data are reviewed at least quarterly and are available in HEIS. Interpretive reports are issued annually in March (e.g., Hartman 1999). Reporting requirements are listed in Table 6.2.

Table 6.1. Critical Means for 28 Comparisons-Background Contamination Indicator Parameter Data for Nonradioactive Dangerous Waste Landfill ${ }^{(a)}$

\begin{tabular}{|c|c|c|c|c|c|c|c|}
\hline Constituent & $\mathbf{n}$ & $\mathrm{df}$ & $t_{c}$ & $\begin{array}{c}\text { Average } \\
\text { Background }\end{array}$ & $\begin{array}{l}\text { Standard } \\
\text { Deviation }\end{array}$ & $\begin{array}{l}\text { Critical } \\
\text { Mean }\end{array}$ & $\begin{array}{c}\text { Upgradient/ } \\
\text { Downgradient } \\
\text { Comparison Value }\end{array}$ \\
\hline $\begin{array}{l}\text { Specific } \\
\text { conductance, } \\
\mu \mathrm{S} / \mathrm{cm}\end{array}$ & 10 & 9 & 5.0255 & 461.65 & 4.845 & 487.2 & 487.2 \\
\hline Field $\mathrm{pH}$ & 11 & 10 & 5.2814 & 7.45 & 0.164 & {$[6.55,8.35]$} & {$[6.55,8.35]$} \\
\hline $\begin{array}{l}\text { Total organic } \\
\text { carbon, }{ }^{(b)} \mu \mathrm{g} / \mathrm{L}\end{array}$ & 11 & 10 & 4.8092 & 380.68 & 242.28 & $1,597.7$ & $1,597.7$ \\
\hline $\begin{array}{l}\text { Total organic } \\
\text { halides, }{ }^{(0, c)} \mu \mathrm{g} / \mathrm{L}\end{array}$ & 11 & 10 & 4.8092 & 4.28 & 2.05 & 14.6 & 22.4 \\
\hline \multicolumn{8}{|c|}{$\begin{array}{l}\text { (a) Data collected from August } 1997 \text { to February } 1999 \text { for upgradient wells } 699 \\
\text { (b) Critical means calculated from values reported below the contractually requ } \\
\text { (c) The upgradient/downgradient comparison value is the limit of quantitation. } \\
\text { df }=\text { Degrees of freedom (n-1). } \\
n=\text { Number of background replicate averages. } \\
t_{c}=\text { Bonferroni critical } t \text {-value for appropriate df and } 28 \text { comparisons. }\end{array}$} \\
\hline
\end{tabular}


Table 6.2. Reports Required for Compliance with 40 CFR 265, Subpart F, for Groundwater Monitoring

\begin{tabular}{|c|c|c|c|}
\hline Submittal & Submittal Period & Reporting Vehicle & $\begin{array}{l}\text { Regulatory } \\
\text { Requirement }^{(\mathrm{a})}\end{array}$ \\
\hline $\begin{array}{l}\text { First year of sampling: concen- } \\
\text { trations of interim primary drink- } \\
\text { ing water constituents, identifying } \\
\text { those that exceed limits. }\end{array}$ & Quarterly & Complete $^{(b)}$ & $\begin{array}{l}40 \text { CFR } \\
265.94(\mathrm{a})(2)(\mathrm{i})\end{array}$ \\
\hline $\begin{array}{l}\text { Concentration and statistical } \\
\text { analyses of groundwater contami- } \\
\text { nation indicator parameters, } \\
\text { noting significant differences in } \\
\text { upgradient wells. }\end{array}$ & $\begin{array}{l}\text { Annually, by } \\
\text { March } 1 \text { of } \\
\text { following year. }\end{array}$ & $\begin{array}{l}\text { Hanford Groundwater } \\
\text { Monitoring Report (e.g., } \\
\text { Hartman 1999(c)) }\end{array}$ & $\begin{array}{l}40 \text { CFR } \\
265.94(a)(2)(i i)\end{array}$ \\
\hline $\begin{array}{l}\text { Results of groundwater surface } \\
\text { elevation evaluation and descrip- } \\
\text { tion of response if appropriate. }\end{array}$ & $\begin{array}{l}\text { Annually, by } \\
\text { March } 1 \text { of } \\
\text { following year. }\end{array}$ & $\begin{array}{l}\text { Hanford Groundwater } \\
\text { Monitoring Report }\end{array}$ & $\begin{array}{l}40 \text { CFR } \\
265.94(a)(2)(\text { iii) }\end{array}$ \\
\hline $\begin{array}{l}\text { Outline for groundwater quality } \\
\text { assessment program }\end{array}$ & $\begin{array}{l}\text { Within } 1 \text { year } \\
\text { after effective } \\
\text { date of } \\
\text { regulations }\end{array}$ & $\begin{array}{l}\text { Chapter } 7 \text { of this } \\
\text { document }\end{array}$ & 40 CFR 265.93(a) \\
\hline $\begin{array}{l}\text { Notification of statistical } \\
\text { exceedance }^{(\mathrm{d})}\end{array}$ & $\begin{array}{l}\text { Within } 7 \text { days of } \\
\text { verification }\end{array}$ & Letter to Ecology & 40 CFR 265.93(c) \\
\hline Assessment Plan ${ }^{(\mathrm{d})}$ & $\begin{array}{l}\text { Within } 15 \text { days } \\
\text { of notification }\end{array}$ & $\begin{array}{l}\text { PNNL document or } \\
\text { letter }\end{array}$ & 40 CFR 265.93(d) \\
\hline $\begin{array}{l}\text { Determinations under assessment } \\
\text { program }^{(d)}\end{array}$ & $\begin{array}{l}\text { As soon as } \\
\text { technically } \\
\text { feasible; annually } \\
\text { thereafter }\end{array}$ & $\begin{array}{l}\text { PNNL document, letter, } \\
\text { or Hanford } \\
\text { Groundwater } \\
\text { Monitoring Report }\end{array}$ & $\begin{array}{l}40 \mathrm{CFR} \\
265.93(\mathrm{~d})(5) \text { and } \\
265.94(\mathrm{~b})\end{array}$ \\
\hline \multicolumn{4}{|c|}{$\begin{array}{l}\text { (a) } 40 \text { CFR 265, U.S. Environmental Protection Agency. "Interim status standards for owners and } \\
\text { operators of hazardous waste treatment, storage, and disposal facilities." } \\
\text { (b) Requirement was fulfilled during first year of sampling via published reports. Quarterly submittal } \\
\text { of data continues via HEIS. } \\
\text { (c) Hartman MJ, ed. } 1999 \text {. Hanford Site groundwater monitoring for fiscal year 1998. PNNL-12086, } \\
\text { Pacific Northwest National Laboratory, Richland, Washington. } \\
\text { (d) Required if exceedance occurs and is verified. }\end{array}$} \\
\hline
\end{tabular}




\subsection{Assessment Monitoring}

This section outlines the assessment monitoring plan for NRDWL, as required by 40 CFR 265.93(a). The assessment program must be capable of determining whether dangerous waste or dangerous waste constituents have entered the groundwater, their concentration, and the rate and extent of migration.

If an indicator parameter at a downgradient well significantly exceeds the background value, an assessment plan will be prepared and submitted to the Washington State Department of Ecology (see Section 6.3). The plan will include the following:

- the approach to determine if dangerous waste or dangerous waste constituents from the facility have entered the groundwater or if the exceedance was caused by other sources (false-positive rationale)

- the investigative approach to fully characterize the rate and extent of contaminant migration

- number, locations, and depths of wells in the monitoring network

- sampling and analytical methods used

- data evaluation procedures

- an implementation schedule.

An outline for the assessment plan is presented in Table 7.1.

As the assessment determinations are made, a report of the findings will be sent to the Washington State Department of Ecology. The determinations will then be updated annually as required by 40 CFR 265.94(b).

Table 7.1. Outline for Groundwater Quality Assessment Monitoring Plan

Introduction
Existing Data and Evaluation
Groundwater Quality Assessment Program
Approach
Assessment Monitoring Network
Constituents
Sampling and Analysis
Data Evaluation
Schedule
References




\subsection{References}

40 CFR 265, U.S. Environmental Protection Agency. "Interim status standards for owners and operators of hazardous waste treatment, storage, and disposal facilities."

DOE - U.S. Department of Energy. 1990. Nonradioactive dangerous waste landfill closure/postclosure plan. DOE/RL-90-17, U.S. Department of Energy, Richland, Washington.

Ecology - Washington State Department of Ecology (Ecology), U.S. Environmental Protection Agency (EPA), and U.S. Department of Energy (DOE). 1989. Hanford Federal Facility Agreement and Consent Order between the U.S. Environmental Protection Agency, the U.S. Department of Energy, and the State of Washington Department of Ecology, May 15, 1989, as amended. Olympia, Seattle, and Richland, Washington.

EPA - U.S. Environmental Protection Agency. 1979. Methods for Chemical Analysis of Water and Wastes. EPA-600/4-79-020, U.S. Environmental Protection Agency, Washington, D.C.

EPA - U.S. Environmental Protection Agency. 1986a. RCRA groundwater monitoring technical enforcement guidance document. U.S. Environmental Protection Agency, Washington, D.C.

EPA - U.S. Environmental Protection Agency. 1986b. Test methods for evaluating solid wastes: physical/chemical methods, $3^{\text {rd }}$ ed., Office of Solid Waste and Emergency Response, U.S. Environmental Protection Agency, Washington, D.C.

ERDA - U.S. Energy Research and Development Agency. 1975. Final environmental statement, waste management operations, Hanford Reservation, Richland, Washington. ERDA-1538, 2 vols., U.S. Energy Research and Development Administration, Richland, Washington.

Gillespie BM. 1999. "Analytical methods." Appendix C in Hanford Site groundwater monitoring for fiscal year 1998. PNNL-12086, Pacific Northwest National Laboratory, Richland, Washington.

Hartman MJ, ed. 1999. Hanford Site groundwater monitoring for fiscal year 1998. PNNL-12086, Pacific Northwest National Laboratory, Richland, Washington.

Hodges FN. 1993a. Interim status groundwater monitoring plan for the Nonradioactive Dangerous Waste Landfill, Hanford, Washington. WHC-SD-EN-AP-026, Rev. 0, Westinghouse Hanford Company, Richland, Washington.

Hodges FN. 1993b. "Nonradioactive Dangerous Waste Landfill." Section 18 in Annual report for RCRA groundwater monitoring projects at Hanford Site facilities for 1992. DOE/RL-93-09, U.S. Department of Energy, Richland Operations Office, Richland, Washington. 
Hodges FN. 1994. "Nonradioactive Dangerous Waste Landfill." Section 5.2 in Annual report for RCRA groundwater monitoring projects at Hanford Site facilities for 1992. DOE/RL-93-88, U.S. Department of Energy, Richland Operations Office, Richland, Washington.

Hodges FN. 1995. Engineering Change Notice 634620. Modifies Interim status groundwater monitoring plan for the Nonradioactive Dangerous Waste Landfill, Hanford, Washington. WHC-SD-EN-AP026, Rev. 0, Westinghouse Hanford Company, Richland, Washington.

Jacques ID and RB Kerkow. 1993. Nonradioactive Dangerous Waste Landfill soil-gas survey: final data report. WHC-SD-EN-TI-199, Rev. 0, Westinghouse Hanford Company, Richland, Washington.

Lindberg JW. 1999. "Hydrogeology of 400 and 600 Areas." Section 3.7 in Hanford Site groundwater monitoring for fiscal year 1998. PNNL-12086, Pacific Northwest National Laboratory, Richland, Washington.

Lindsey KA. 1991. Revised stratigraphy for the Ringold Formation, Hanford Site, south-central Washington. WHC-SD-EN-EE-004, Rev. 0, Westinghouse Hanford Company, Richland, Washington.

Pacific Northwest National Laboratory (PNNL). 1998. The Hanford ground-water monitoring project quality assurance project plan. QA Plan ETD-012, Rev. 1, Pacific Northwest National Laboratory, Richland, Washington.

Resource Conservation and Recovery Act. 1976. Public Law 94-580, as amended, 90 Stat. 2795, 42 USC 6901 et seq.

WAC 173-303, Washington Administrative Code. Dangerous waste regulations. Olympia, Washington.

Waste Management Federal Services. 1998. Waste Management Northwest Procedure Manual. ES-SSPM-001, Waste Management Northwest, Richland, Washington.

Weekes DC, SP Luttrell, and MR Fuchs. 1987. Interim hydrogeologic characterization report and groundwater monitoring system for the Nonradioactive Dangerous Waste Landfill, Hanford Site, Washington. WHC-EP-0021, Westinghouse Hanford Company, Richland, Washington. 


\section{Appendix A}

Construction Details of the Wells in the Monitoring Network 


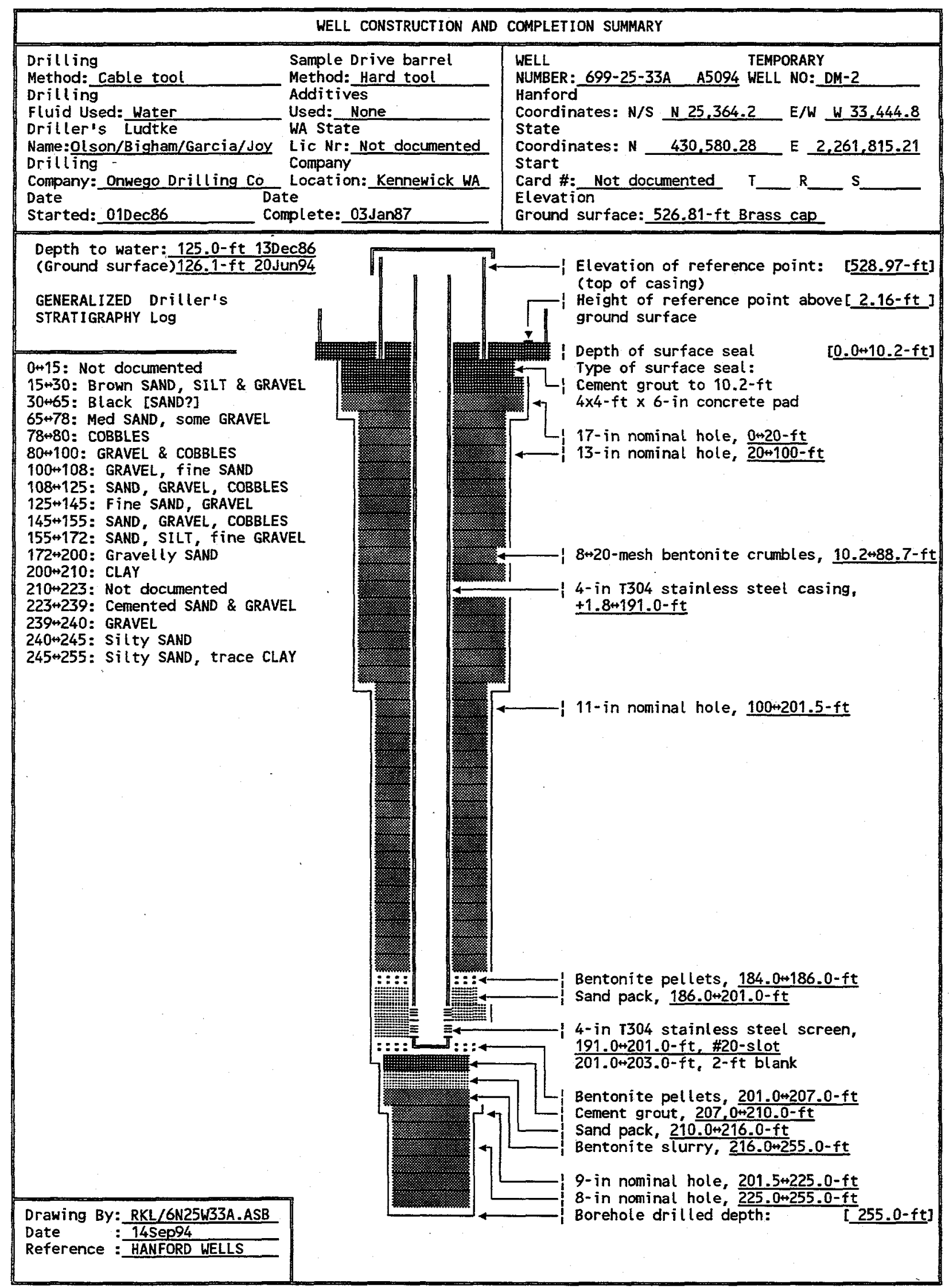




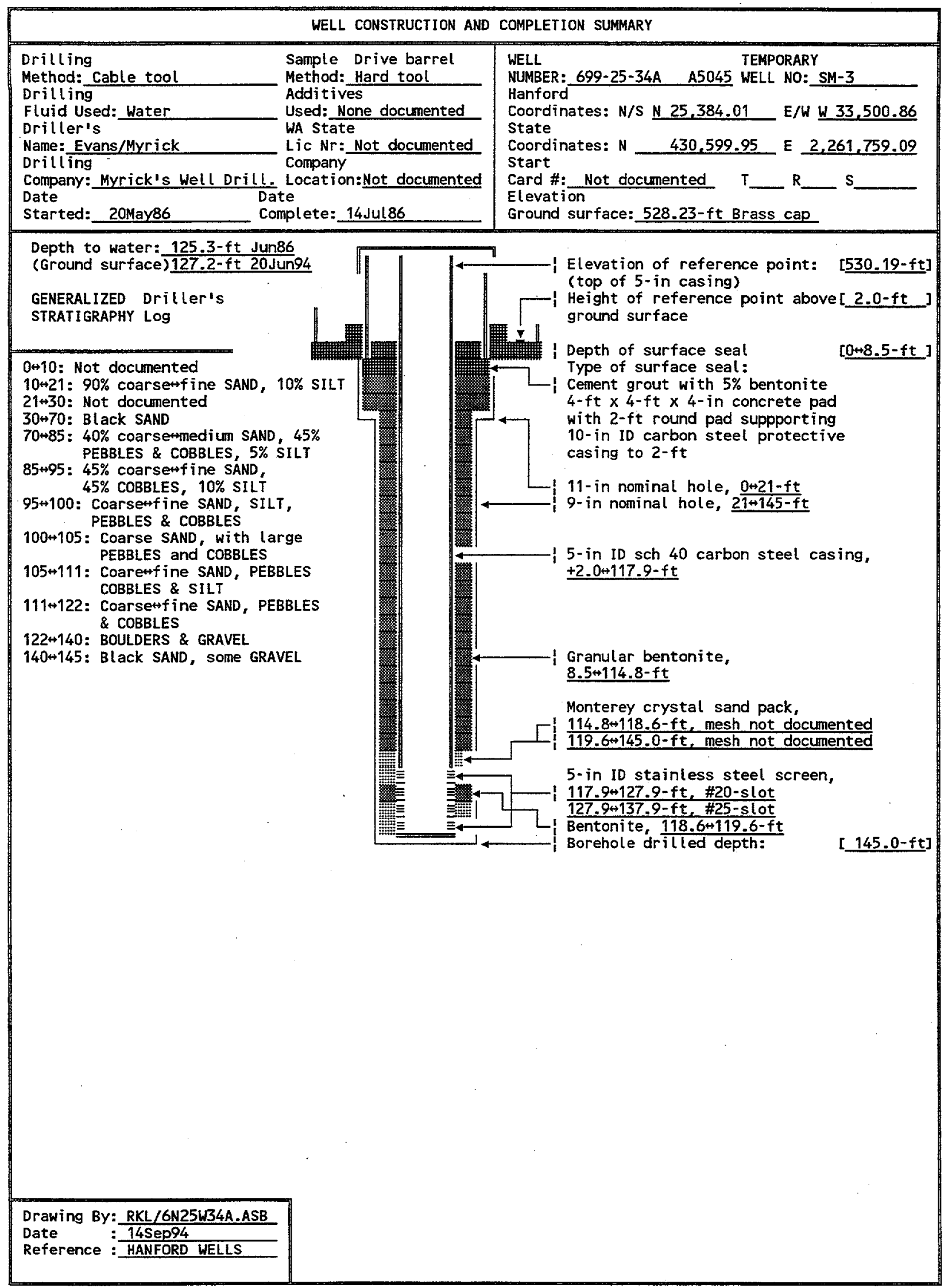




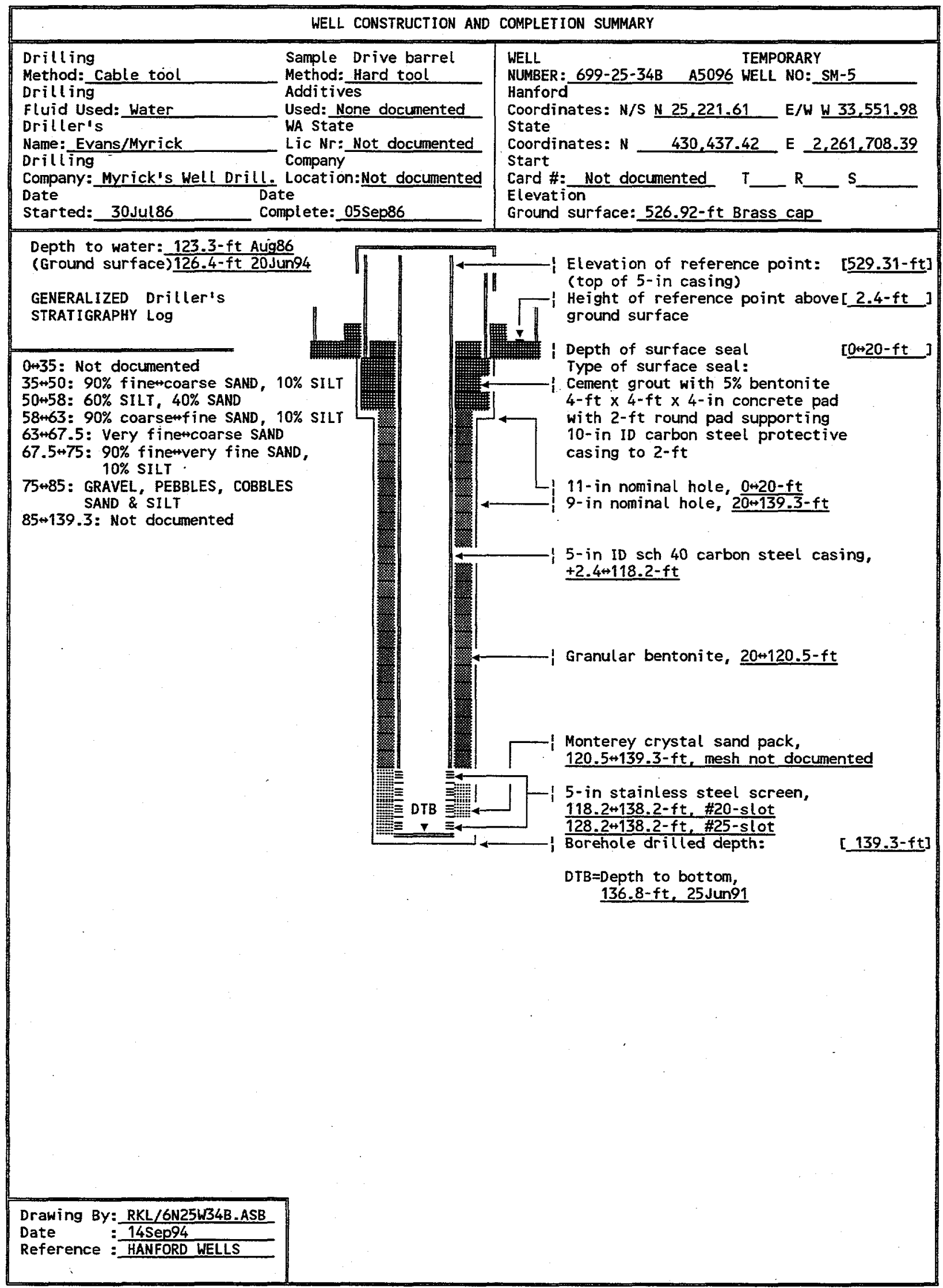




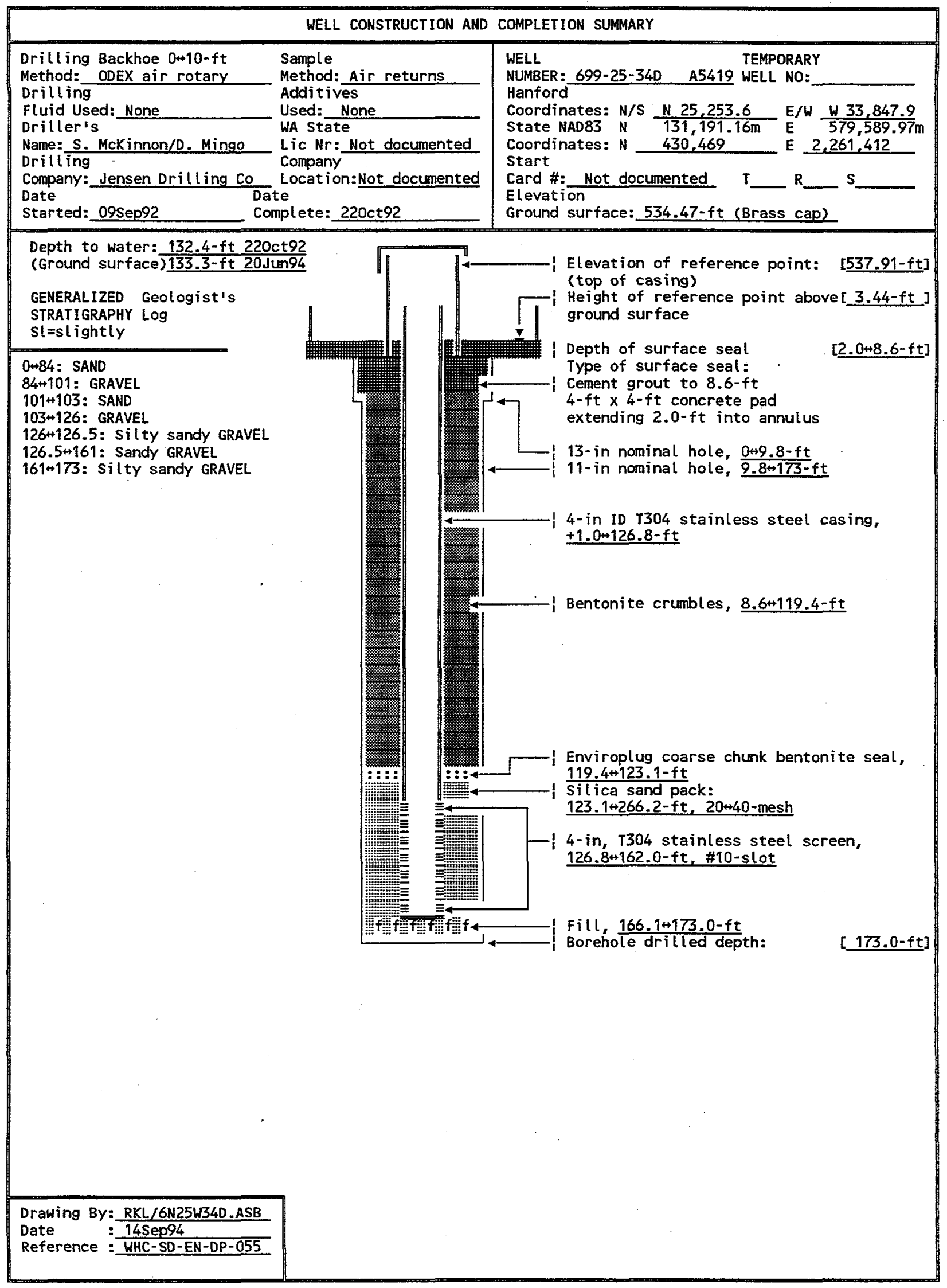




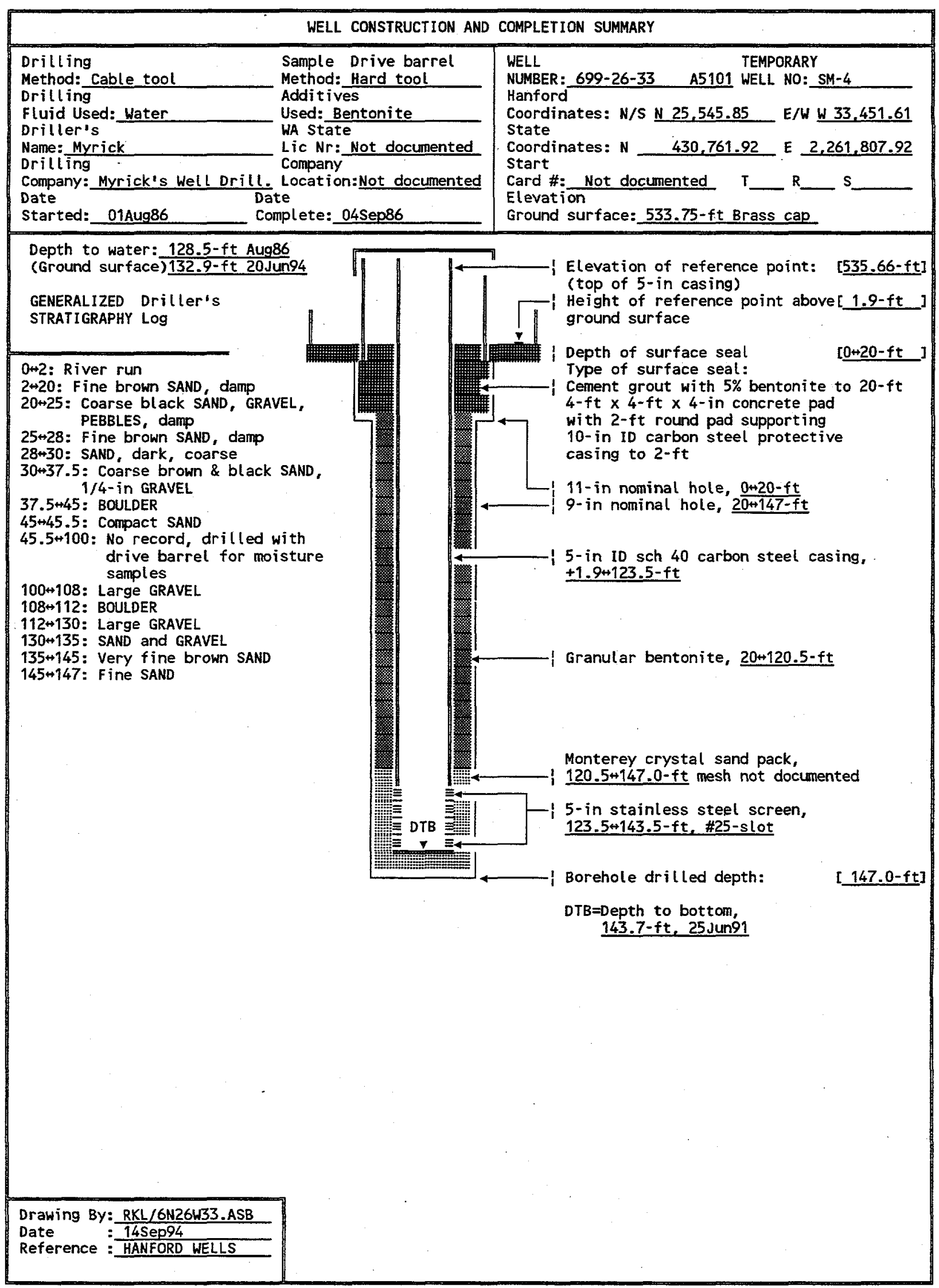


WELL CONSTRUCTION AND COMPLETION SUMMARY

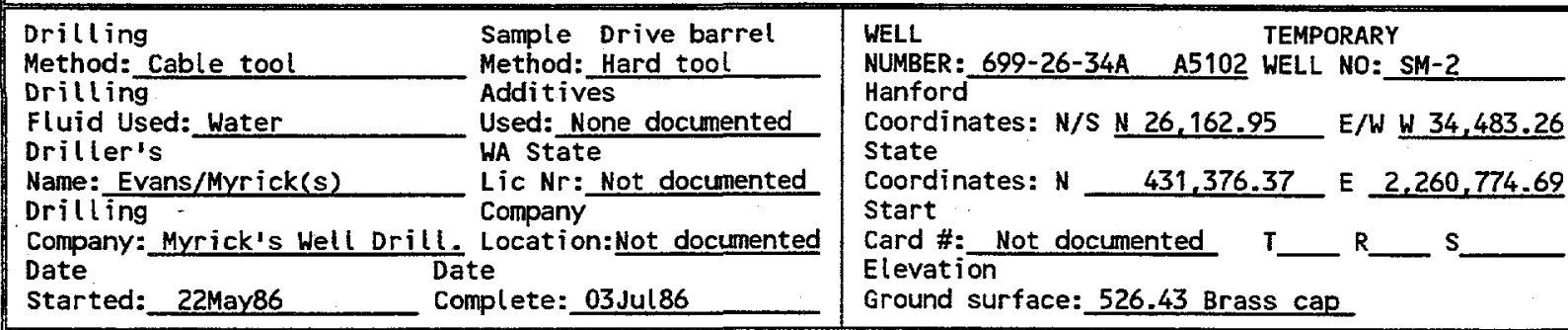

Depth to water: $121.5-\mathrm{ft}$ Jun86

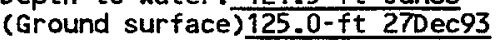

GENERALIZED Driller's STRATIGRAPHY LOg

$0475:$ Not documented

$75+81$ : Large GRAVEL and fine SAND 81+120: Not documented, drive barrel 120 +136 : BOULDER or BOULDERS

136 +143 : SAND (heaving)
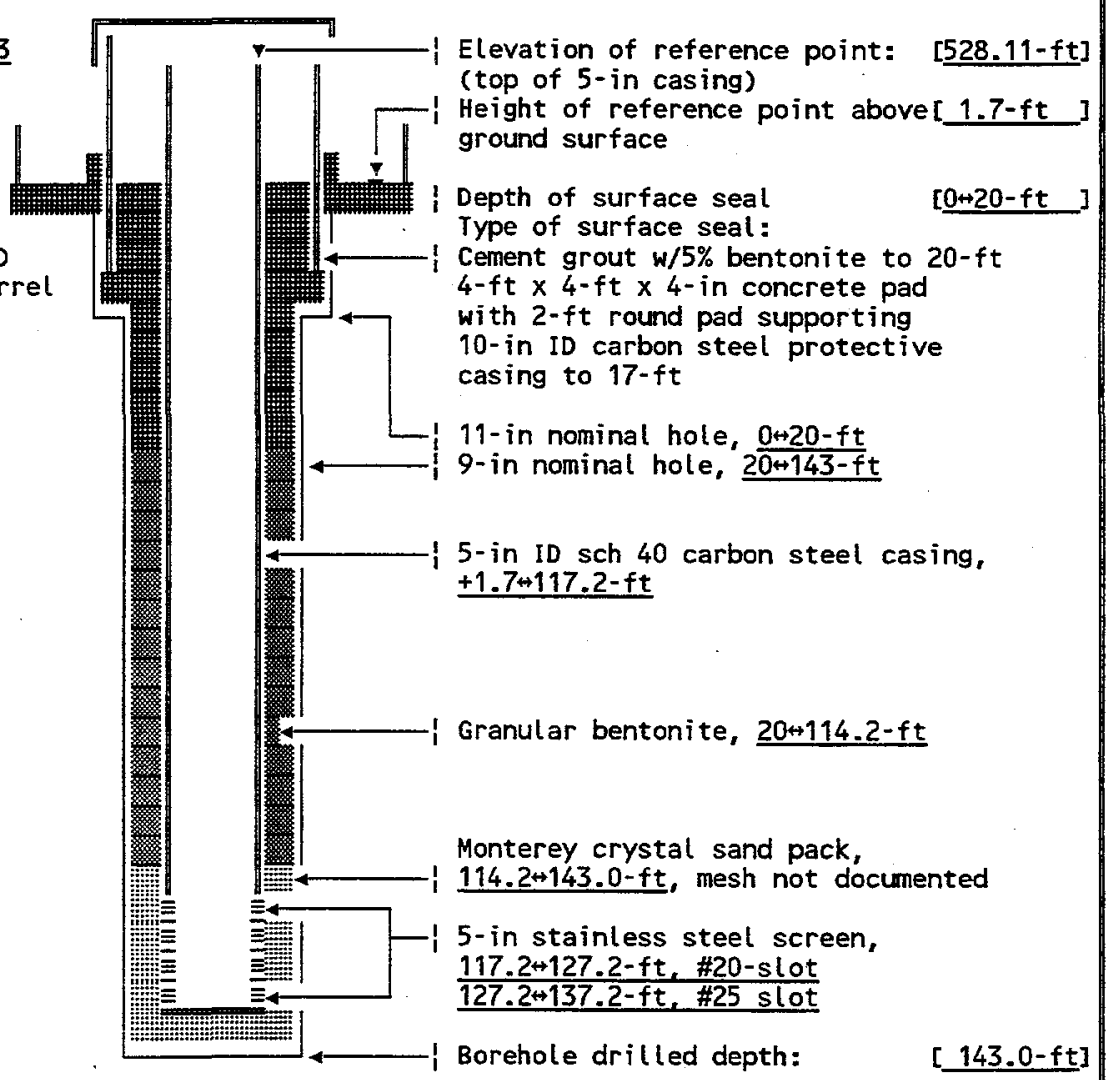

Drawing By: RKL/6N26W/34A.ASB

Date : 14Sen94

Reference: HANFORD WELLS 


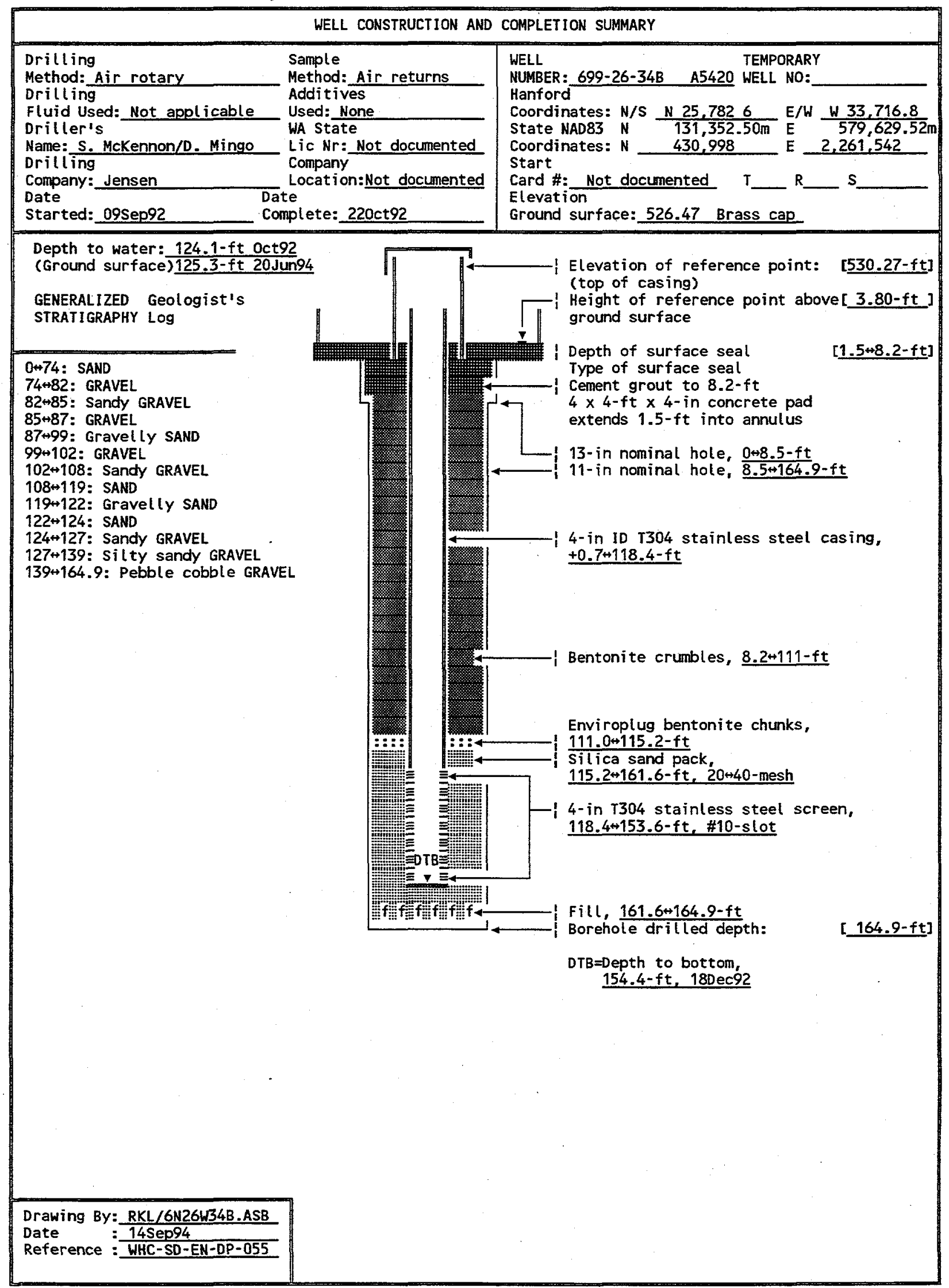




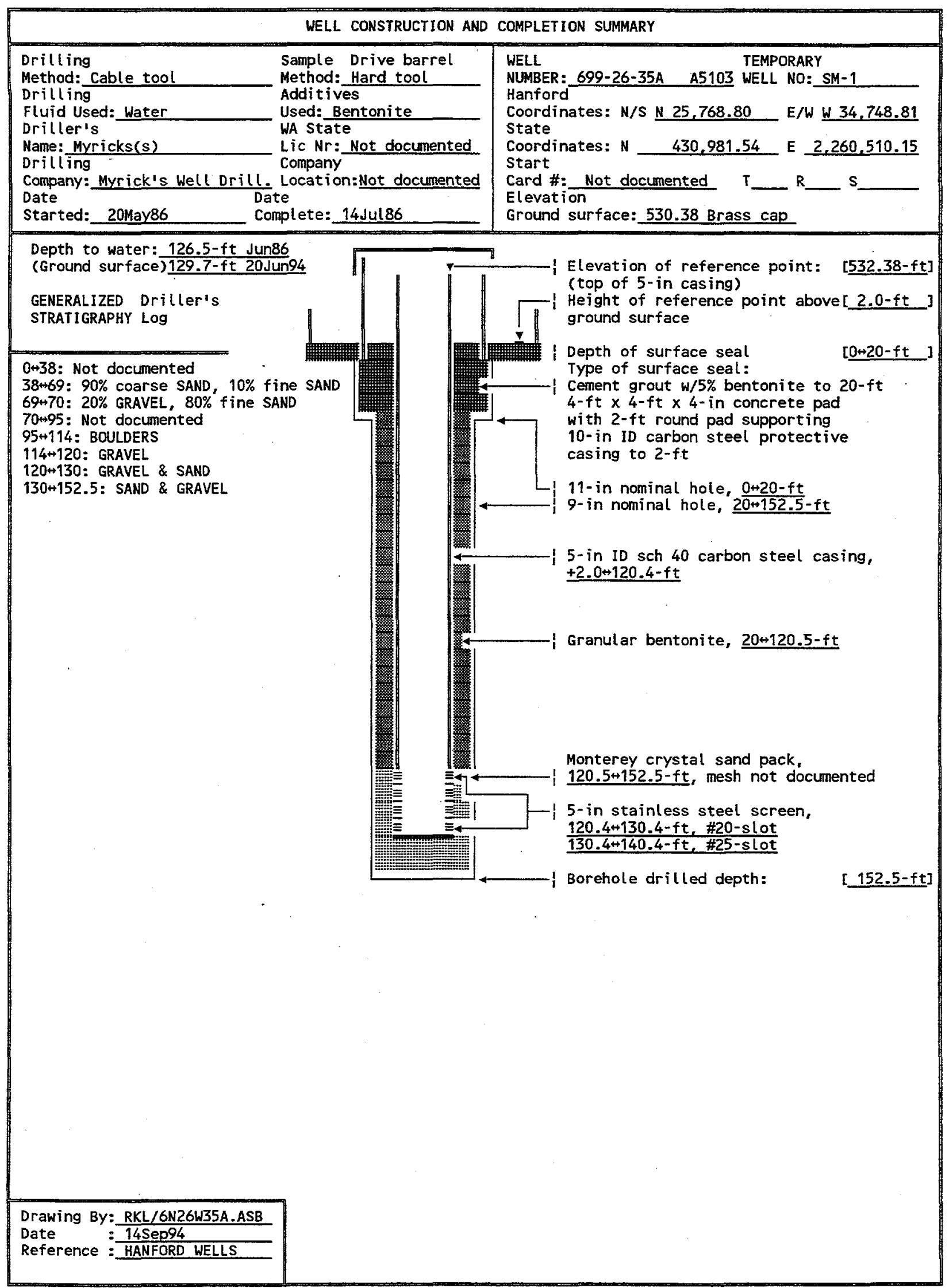




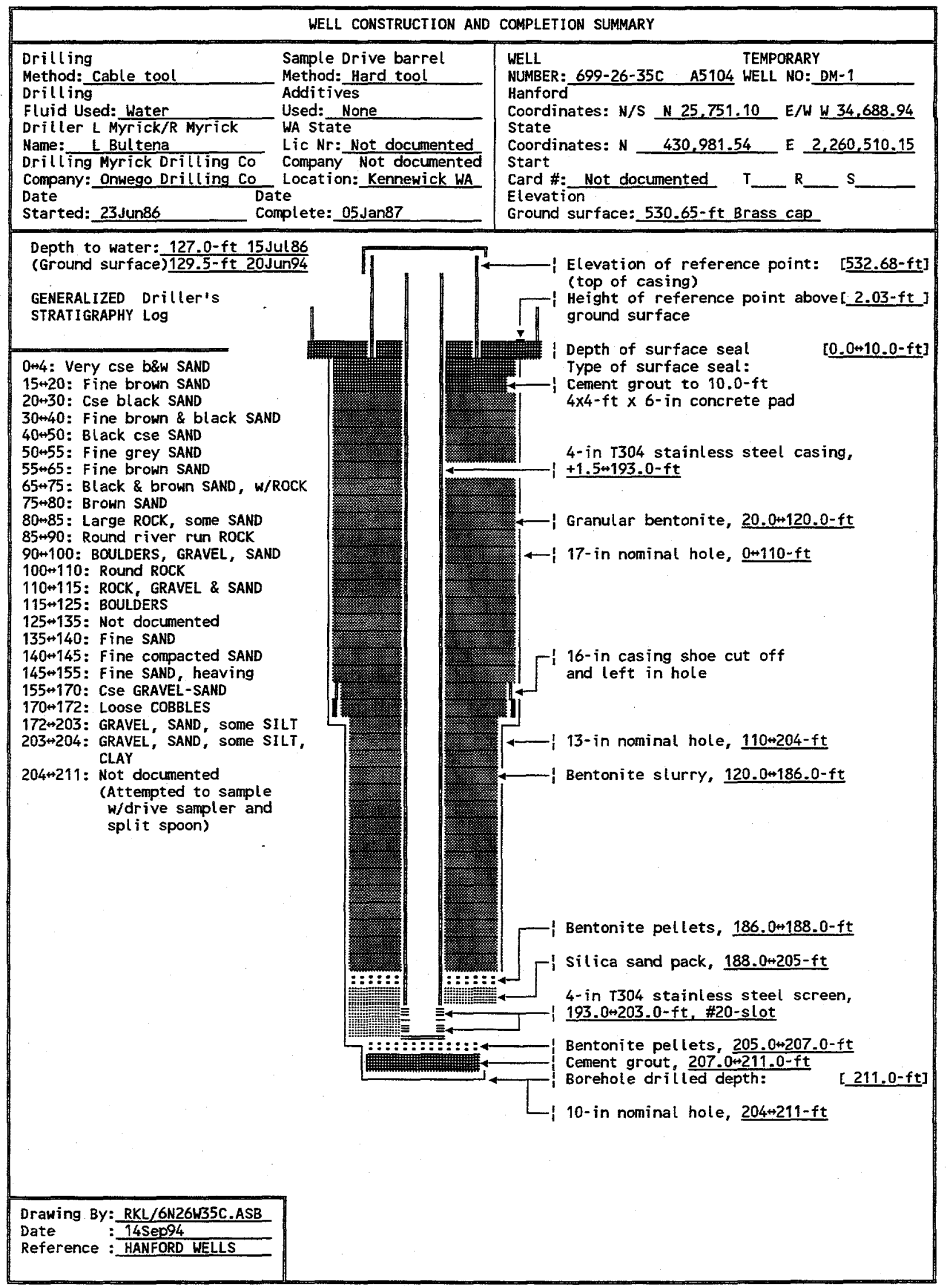




\section{Distribution}

No. of

Copies

\section{ONSITE}

2 DOE Richland Operation Office

M. J. Furman

K. M. Thompson

4 Bechtel Hanford, Inc.
B. H. Ford
G. C. Henckel
G. S. Robinson
B. L. Veder

CH2M Hill Hanford, Inc.
No. of

Copies

\section{State of Washington Department of Ecology}

Jack Donnelly

B5-18

Stan Leja

B5-18
$\mathrm{H} 0-12$

21 Pacific Northwest National Laboratory

C. J. Chou

M. J. Hartman (5)

J. W. Lindberg (5)

S. P. Luttrell

L. F. Morasch

R. M. Smith

Information Release Office (7)
K6-81

K6-81

K6-81

K6-81

K6-86

K6-81

K1-06

H9-03

Distr.1 